\title{
Pubertal high fat diet: effects on mammary cancer development
}

Yong Zhao', Ying Siow Tan', Mark D Aupperlee ${ }^{1}$, Ingeborg M Langohr ${ }^{3}$, Erin L Kirk ${ }^{4}$, Melissa A Troester ${ }^{4,5}$, Richard C Schwartz $2^{2^{*}}$ and Sandra Z Haslam ${ }^{1,6^{*}}$

\begin{abstract}
Introduction: Epidemiological studies linking dietary fat intake and obesity to breast cancer risk have produced inconsistent results. This may be due to the difficulty of dissociating fat intake from obesity, and/or the lack of defined periods of exposure in these studies. The pubertal mammary gland is highly sensitive to cancer-causing agents. We assessed how high fat diet (HFD) affects inflammation, proliferative, and developmental events in the pubertal gland, since dysregulation of these can promote mammary tumorigenesis. To test the effect of HFD initiated during puberty on tumorigenesis, we utilized BALB/C mice, for which HFD neither induces obesity nor metabolic syndrome, allowing dissociation of HFD effects from other conditions associated with HFD.
\end{abstract}

Methods: Pubertal BALB/c mice were fed a low fat diet (12\% kcal fat) or a HFD (60\% kcal fat), and subjected to carcinogen 7,12-dimethylbenz[a]anthracene (DMBA)-induced tumorigenesis.

Results: HFD elevated mammary gland expression of inflammatory and growth factor genes at 3 and 4 weeks of diet. Receptor activator of nuclear factor kappa-B ligand (RANKL), robustly induced at 4 weeks, has direct mitogenic activity in mammary epithelial cells and, as a potent inducer of NF-KB activity, may induce inflammatory genes. Three weeks of HFD induced a transient influx of eosinophils into the mammary gland, consistent with elevated inflammatory factors. At 10 weeks, prior to the appearance of palpable tumors, there were increased numbers of abnormal mammary epithelial lesions, enhanced cellular proliferation, increased growth factors, chemokines associated with immune-suppressive regulatory T cells, increased vascularization, and elevated M2 macrophages. HFD dramatically reduced tumor latency. Early developing tumors were more proliferative and were associated with increased levels of tumor-related growth factors, including increased plasma levels of HGF in tumor-bearing animals. Early HFD tumors also had increased vascularization, and more intra-tumor and stromal M2 macrophages.

Conclusions: Taken together in this non-obesogenic context, HFD promotion of inflammatory processes, as well as local and systemically increased growth factor expression, are likely responsible for the enhanced tumorigenesis. It is noteworthy that although DMBA mutagenesis is virtually random in its targeting of genes in tumorigenesis, the short latency tumors arising in animals on HFD showed a unique gene expression profile, highlighting the potent overarching influence of HFD.

\footnotetext{
* Correspondence: schwart9@msu.edu; shaslam@msu.edu

Department of Microbiology and Molecular Genetics, Breast Cancer and the

Environment Research Program, Michigan State University, East Lansing, Ml

48824, USA

${ }^{1}$ Breast Cancer and the Environment Research Program, Department of

Physiology, Michigan State University, East Lansing, MI 48824, USA

Full list of author information is available at the end of the article
}

\section{Biomed Central}

(c) 2013 Zhao et al.; licensee BioMed Central Ltd. This is an open access article distributed under the terms of the Creative Commons Attribution License (http://creativecommons.org/licenses/by/2.0), which permits unrestricted use, distribution, and reproduction in any medium, provided the original work is properly cited. 


\section{Introduction}

Eradication of breast cancer will be significantly advanced by the development of effective prevention strategies. Dietary fat intake and increased body mass index (BMI)/ obesity have been studied for their potential contributions to breast cancer risk. High BMI (BMI $\geq 25 \mathrm{~kg} / \mathrm{m}^{2}$ ) is a recognized risk factor for postmenopausal breast cancer in the pooled analysis of data from large, prospective cohort studies [1]. Conversely, in the same analysis, high BMI (BMI >31) is associated with reduced risk for premenopausal breast cancer [1]. Similarly, weight gain in adult years is associated with increased risk for postmenopausal breast cancer and reduced risk for premenopausal breast cancer [2]. The relationship between dietary factors, specifically dietary fat, the major contributor to increased BMI, and breast cancer risk is less clear. Recent research has demonstrated no associations with breast cancer risk for adult intake of total fat, saturated fat, or other specific types of dietary fat. These findings did not vary by ethnicity, estrogen/progesterone receptor status, tumor stage, BMI, hormone replacement therapy use, follow-up period, family history of breast cancer, or smoking status at baseline [3]. Lack of associations between dietary factors and breast cancer risk could be the result of numerous sources of bias, including misclassification of dietary intake. Furthermore, the time period in which diet may play the most important role is unclear. In this regard, dietary data usually reflect diet for the year prior to diagnosis or in adulthood prior to breast cancer. Thus, there is a need for a better understanding of the relative contributions of diet, and the timing of diet and/or obesity, to breast cancer risk.

Based on studies in humans and rodents, there is now wide recognition that the origins of breast cancer probably occur early in development, especially during the times of rapid breast development in the pubertal transition [4]. Emerging evidence indicates that the composition, cellular proliferation, and maturation of the gland can be altered by diet and environmental exposures, and that exposure during puberty is particularly relevant [5]. An important gap in our understanding is how diet and/ or increased BMI specifically influence pubertal breast development and breast cancer risk in adulthood. The typical western diet, high in saturated fat, is largely credited for the obesity epidemic in the US. However, it should be noted that there are more people who eat a high-fat western diet and potentially suffer its consequences, than are actually obese. At the same time, the effects of diet versus those of increased BMI are difficult to distinguish, since a high fat diet (HFD) often results in increased BMI.

Among the mechanisms proposed for diet/obesityassociated breast cancer risk are altered glucose metabolism, altered steroid hormone levels, and inflammatory processes [6]. It is entirely possible that HFD during puberty may alter breast development, independently of increasing BMI, through one or more of these mechanisms, thereby modifying the risk for breast cancer.

Ovarian hormones and growth factors are primary factors driving pubertal mammary gland development in humans and rodents. Estrogen (E) and progesterone (P) promote epithelial cell proliferation by inducing amphiregulin (Areg), a growth factor produced in estrogen receptor $\alpha(E R \alpha)$ - and progesterone receptor (PR)positive cells, that acts through a paracrine mechanism in the stroma and in ER negative mammary epithelial cells $[7,8]$.

Macrophages and eosinophils play important roles in normal pubertal mammary gland development in the mouse [9] and, in the case of macrophages, also contribute to mammary tumor progression [10]. Macrophage association with terminal end buds is needed for ductal elongation and eosinophils are required for proper ductal development, particularly branching. Mast cells have also been implicated in pubertal mammary gland ductal morphogenesis, with a role independent of that of macrophages [11]. Importantly, inflammatory leukocytes are involved in several animal models of mammary tumor progression [12,13]. A diet high in saturated fat, that may increase inflammatory processes in the mammary gland, may also promote mammary tumorigenesis [14-17].

We previously investigated the impact of HFD on pubertal mammary gland development in BALB/c mice [18]. Pubertal mice were fed non-isocaloric diets that were either high in saturated fat (HFD, 60\% kcal from fat) or low in saturated fat (LFD, $12 \% \mathrm{kcal}$ from fat) during the peri-pubertal period from 3 to 7 weeks of age. Notably, HFD significantly increased mammary epithelial cell proliferation without a significant increase in body weight [18]. That study showed a small increase in fasting blood glucose and plasma insulin levels, and no difference in plasma E levels after 4 weeks on the diets.

The purpose of the present study was to investigate the effects of HFD initiated in the peri-pubertal period on mammary gland susceptibility to DMBA-induced mammary tumorigenesis in adulthood in a non-obesogenic context in BALB/c mice. We sought to examine the potential effects on proliferation, inflammatory processes, glucose metabolism and altered hormone levels in the context of mammary tumorigenesis.

The results obtained showed a significant decrease in tumor latency in HFD-fed mice. The association of HFD-induced decreased latency with local and systemically increased growth factor expression, and promotion of inflammatory and angiogenic processes, suggest likely mechanisms for enhanced tumorigenicity. Importantly, these HFD-induced effects occurred without significant 
body weight gain, obesity, or major effects on glucose and insulin levels, or E and P levels. Furthermore, tumors occurring with reduced latency on HFD displayed a gene expression profile that clearly distinguished them from tumors occurring on LFD.

\section{Materials and methods \\ Animals}

Three-week-old female BALB/c mice were obtained from Charles River Laboratories (Portage, MI, USA). Mothers of these mice were maintained on LabDiet 5 L79 (PMI Nutrition International LLC, St. Louis, MO, USA) before and during pregnancy, and while nursing. Upon arrival, mice were randomly distributed into two non-isocaloric diet groups, LFD or HFD. Animals were housed in polysulfone cages, and received measured amounts of food and water ad libitum. Housing facilities were maintained on a 12:12 h light-dark cycle, at 20 to $24^{\circ} \mathrm{C}$ with 40 to $50 \%$ relative humidity. All animal experimentation was conducted in accord with accepted standards of humane animal care and approved by the All University Committee on Animal Use and Care at Michigan State University.

\section{Diets}

Diets were initiated at 3 weeks of age and maintained throughout the experimental period up to 45 weeks of age. Two diets (I and II) were used in these studies. Diet I: low fat diet $58 \mathrm{G} 7(12 \% \mathrm{kcal}$ fat - LFD) and high fat diet 58G9 $(60 \% \mathrm{kcal}$ fat - HFD) were purchased from TestDiet (PMI Nutrition International LLC). Initial concern over the carbohydrate content of Diet I and the potential for the development of metabolic syndrome led us to also use Diet II, which contained maltodextrin instead of the dextrin and sucrose contained in Diet I. Diet II: low fat diet 12450B (10\% kcal fat - LFD) and high fat diet 12492 (60\% kcal fat - HFD), both with corn oil replacing soy oil, were purchased from Research Diets (New Brunswick, NJ, USA). For Diet I, 11\% kcal fat came from corn oil, with the remainder of the fat (1 or $49 \% \mathrm{kcal}$ ) coming from lard. For Diet II, $5.5 \% \mathrm{kcal}$ fat came from corn oil, with the remainder of the fat (4.5 or $54.5 \% \mathrm{kcal}$ ) coming from lard. Detailed composition of Diets I and II is described in Additional file 1. LFD and HFD Diets I and II did not differ significantly with regard to their effects on body weight, blood glucose, insulin levels, tumor incidence, or tumor latencies (see Additional files $2,3,4,5)$. Therefore, results obtained on tumorigenesis with the two diets were combined.

\section{Tumorigenesis}

Mice were treated with 7,12-dimethylbenz(a)anthracene (DMBA) (Sigma-Aldrich, St. Louis, MO, USA) prepared in vegetable oil and administered by oral gavage $(50 \mathrm{mg} / \mathrm{kg}$ body weight/mouse) once per week for 4 weeks starting at 5 weeks of age. Body weights were monitored weekly, and animals were palpated for tumors once a week starting at 8 weeks post first DMBA dose (see Additional file 6). Tumor volume was measured twice per week, and harvested at $1 \mathrm{~cm}$ size. At $2 \mathrm{~h}$ prior to sacrifice, mice were injected with 5-bromo-2'-deoxyuridine (BrdU) $(70 \mu \mathrm{g} / \mathrm{g}$ body weight; Sigma-Aldrich) for analysis of cellular proliferation. At termination of all feeding studies, portions of tumors and mammary tissues were either snap frozen for protein and RNA isolation, or formalin fixed and either processed as whole mounts [19] or paraffin embedded for H\&E staining and immunohistochemistry [20]. Wholemount preparations of glands and $\mathrm{H} \& \mathrm{E}$ sections were scored for the presence of hyperplasia and neoplasia [21]. There were no notable diet effects on mammary gland morphology as assessed by whole mounts or histological sections at the time points analyzed. All lesions and tumors were reviewed and classified, as previously described [22].

\section{Metabolic parameters}

Plasma glucose and insulin levels were the metabolic parameters measured. Non-fasting, randomly sampled glucose and insulin levels were obtained from mice fed ad libitum, as an appropriate and acceptable method based on mouse feeding habits and the stress caused by fasting [23]. Plasma levels of glucose were determined by AccuChek Compact Glucometer (Roche, Nutley, NJ, USA) and insulin levels were determined with an insulin ELISA kit from EMD Millipore (Cat. number: EZRMI-13 K; St. Charles, MO, USA), following the manufacturer's instructions.

\section{Estrogen and progesterone assay}

Total serum E levels were determined using Delfia Estradiol time-resolved fluoroimmunoassay (Cat. number: 1244-056; PerkinElmer, Turku, Finland), following the manufacturer's instructions. The levels of serum $\mathrm{P}$ were measured by ELISA (Cat. number: 11-PROHU-E01; Alpco Diagnostics, Salem, NH, USA), following the manufacturer's instructions.

\section{Estrogen receptor analysis}

Mammary gland or tumor sections $(5 \mu \mathrm{m})$ were prepared and subjected to antigen retrieval and immunofluorescent staining, as previously described [20]. Briefly, sections were blocked with goat anti-mouse immunoglobulin G (IgG) Fab (antigen binding fragment; 1:100 with $1 \%$ BSA in PBS (PBSA)) for $1 \mathrm{~h}$ at room temperature (RT), followed by blocking with normal goat serum in PBS for 30 minutes at RT. Then, sections were incubated with mouse anti-ER $\alpha$ (1:10 in PBS- $0.5 \%$ Triton X-100; Cat. number: NCL-ER-6 F11; Novocastra Laboratories Ltd, Newcastle upon Tyne, UK) at $4{ }^{\circ} \mathrm{C}$ 
overnight. After a brief wash, sections were incubated with an Alexa 488-labeled goat anti-mouse secondary antibody (Ab) (1:200 in PBS; Invitrogen Molecular Probes, Grand Island, NY, USA) at RT for 30 minutes, and then counterstained with 4,6-diamidino-2-phenylindole (DAPI) for 5 minutes. The stained sections were visualized with a Nikon Eclipse TE2000-U fluorescence microscope (Nikon, Inc., Melville, NY, USA) using a 40X objective lens, and the captured fluorescent images were analyzed using MetaMorph software (Molecular Devices, LLC, Sunnyvale, CA, USA). A minimum of 1,000 cells were counted for each tumor. Tumors were considered to be ER $\alpha$-positive (ER+) if $10 \%$ or more of the total cells counted were ER + [24].

\section{Macrophage analysis}

Mammary gland or tumor sections $(5 \mu \mathrm{m})$ were prepared for immunofluorescent staining [20]. Briefly, after deparaffinization, mammary gland sections were subjected to antigen retrieval at $121^{\circ} \mathrm{C}$ and 15 pounds per square inch (psi) for 5 minutes; tumor sections did not receive antigen retrieval, as the integrity of tumor sections was compromised by the procedure, and staining was adequate in its absence. All sections were treated with proteinase $\mathrm{K}(20 \mu \mathrm{g} / \mathrm{mL}$ in Tris-EDTA buffer, $\mathrm{pH} 8.0$ ) at $37^{\circ} \mathrm{C}$ for 3.5 minutes. After brief washes with PBS, sections were blocked with normal rabbit serum in PBS, followed by incubation with goat anti-Arginase 1 (Arg1) (1:200 in PBS-0.5\% Triton X-100; Cat. number: sc-18354; Santa Cruz Biotechnology, Inc., Santa Cruz, CA, USA) at $4^{\circ} \mathrm{C}$ overnight. After brief washes, sections were incubated with Alexa 546-labeled rabbit anti-goat secondary Ab (1:100 in PBS; Cat. number: A21085; Invitrogen Molecular Probes) at RT for 30 minutes and then blocked with normal goat serum in PBS for 30 minutes. The sections were then incubated with rat monoclonal anti-F4/80 (1:75 in PBS-0.5\% Triton X-100; Cat. number: MCA497R; AbD Serotec, Raleigh, NC, USA) at $4^{\circ} \mathrm{C}$ overnight, followed by incubation with Alexa 488labeled goat anti-rat secondary Ab (1:100 in PBS; Invitrogen Molecular Probes) at RT for 30 minutes and counterstaining with DAPI for 5 minutes. The stained sections were visualized with a Nikon Eclipse TE2000-U fluorescence microscope (Nikon, Inc.) using a 40X objective lens, and the captured fluorescent images were analyzed using MetaMorph software (Molecular Devices, LLC). The number of F4/80 and/or Arg1-positive cells is expressed as cells per structure in the mammary gland peri-epithelial area, and cells per image in tumor samples.

\section{Cellular proliferation analysis}

Mammary gland or tumor sections $(5 \mu \mathrm{m})$ were prepared and immunoperoxidase staining was performed [20].
Briefly, after deparaffinization, sections were incubated in $3 \%$ of hydrogen peroxide $\left(\mathrm{H}_{2} \mathrm{O}_{2}\right)$ in methanol for 10 minutes. Then sections were subjected to antigen retrieval at $121^{\circ} \mathrm{C}$ and $15 \mathrm{psi}$ for 15 minutes. Sections were blocked with goat anti-mouse IgG Fab (1:100 in $1 \%$ PBSA) for $1 \mathrm{~h}$, followed by blocking with normal goat serum in PBS. Then, sections were incubated with mouse anti-BrdU (1:100 in PBS-0.5\% Triton X-100; Cat. number: ab27958; Abcam plc, Cambridge, MA, USA) at $4^{\circ} \mathrm{C}$ overnight. After a brief wash, sections were incubated with goat anti-mouse biotin secondary Ab (1:400 in PBS; DAKO Denmark A/S, Glostrup, Denmark) at RT for 30 minutes, and then incubated with $\mathrm{ABC}$ reagent (PK7100, Vector laboratories, Inc., Burlingame CA, USA) for 30 minutes. The sections were then incubated with metalenhanced 3,3-diaminobenzidine (DAB) substrate solution $(100 \mu \mathrm{L}$ of DAB substrate $+900 \mu \mathrm{L}$ stable peroxide substrate buffer; Thermo Scientific, Rockford, IL, USA) for 7 minutes and counterstained with hematoxylin for 2 minutes. The stained sections were visualized with a Nikon Eclipse E400 light microscope (Nikon, Inc.) using a 40X objective lens. A minimum of 1,000 cells were counted for each section, and a minimum of two to three tissue sections per animal were analyzed. The number of BrdU-positive cells is expressed as the percentage of total epithelial cells counted.

\section{Immunohistochemical analysis of blood vessel density}

Mammary gland or tumor sections $(5 \mu \mathrm{m})$ were deparaffinized and were incubated in $2 \% \mathrm{H}_{2} \mathrm{O}_{2}$ in methanol/ PBS (1:1 ratio) for 30 minutes followed by antigen retrieval by boiling at $95^{\circ} \mathrm{C}$ for 5 minutes. Sections were then treated for $2 \mathrm{~h}$ with rabbit anti-CD31 (1:50 in PBS-0.5\% Triton X-100; Cat. number: AP15436PU-N; Acris Antibodies, Inc., San Diego, CA, USA) for endothelial cell staining and detection of blood vessels. After a brief wash, sections were incubated with secondary swine anti-rabbit $\mathrm{Ab}$ at RT for 30 minutes, and then incubated with $\mathrm{ABC}$ reagent (PK-7100, Vector laboratories, Inc.) for 30 minutes. The sections were then incubated with metal-enhanced DAB substrate solution $(100 \mu \mathrm{L}$ of DAB substrate $+900 \mu \mathrm{L}$ stable peroxide substrate buffer; Thermo Scientific) for 7 minutes and counterstained with hematoxylin for 2 minutes. The stained sections were visualized with a Nikon Eclipse E400 light microscope (Nikon, Inc.) using a 40X objective lens. A minimum of 1,000 cells were counted for each section, and a minimum of two to three tissue sections per animal were analyzed. Digital micrographs were captured and the images were overlaid with grids containing 240 squares $\left(324 \mu^{2} /\right.$ square). Blood vessel density is expressed as the percentage of CD31-positive squares. 


\section{Eosinophil and mast cell analysis}

Deparaffinized 5- $\mu \mathrm{m}$ sections were stained with Astra Blue/Vital New Red [25]. Sections dehydrated in 95\% ethanol for $5 \mathrm{sec}$ were incubated in Astra Blue solution ( $5 \mathrm{mg} / \mathrm{mL}$ in $75 \%$ ethanol) for 30 minutes at RT. After rinsing in double-distilled water $\left(\mathrm{H}_{2} \mathrm{O}\right)$, sections were again dehydrated in 95\% ethanol for $5 \mathrm{sec}$, and then incubated in Vital New Red solution $(0.2 \mathrm{~g} / \mathrm{L}$ in $50 \%$ ethanol) for $1 \mathrm{~h}$ at RT and counterstained with hematoxylin for 2 minutes. The stained sections were visualized with a Nikon Eclipse E400 light microscope (Nikon, Inc.) using a 40X objective lens. The number of eosinophils and mast cells is expressed as cells per structure in the mammary gland peri-epithelial area.

\section{Mammary gland structure analysis}

Sections stained for macrophages, cellular proliferation, eosinophils, and mast cells were analyzed by mammary gland epithelial structure: small ducts, large ducts, terminal end buds (TEBs), or hyperplastic foci. Large ducts were qualitatively characterized by larger lumen diameter, comprising greater than 50 cells in a section, and by an extensive extracellular matrix and fibroblasts surrounding the epithelium. Conversely, small ducts were qualitatively characterized by smaller lumen diameter, comprising fewer than 50 cells, and by a limited extracellular matrix surrounding the epithelium. TEBs were characterized by location within the gland, presence of multiple epithelial cell layers, and direct apposition of epithelium to adipocytes without extracellular matrix. Hyperplastic structures had multiple cell layers of noticeably distorted epithelium compared to normal epithelial structures.

\section{Quantitative PCR arrays and quantitative reverse transcription-PCR analysis (qRT-PCR)}

Total RNA was isolated from mouse mammary glands (intact or cleared fat pads) or tumors using $\mathrm{TRIzol}^{\circledR}$ reagent (Invitrogen, Carlsbad, CA, USA) and purified using the $\mathrm{RT}^{2}$ qPCR-Grade RNA isolation kit (SABiosciences, Frederick, MD, USA). We used $3 \mu \mathrm{g}$ of total RNA for first strand cDNA synthesis using the $\mathrm{RT}^{2}$ First Strand kit (SABiosciences), following the manufacturer's instructions. The cDNA $(20 \mu \mathrm{L})$ were diluted to $150 \mu \mathrm{L}$ with de-ionized $\mathrm{H}_{2} \mathrm{O}$. RNA expression was then analyzed using targeted PCR arrays (SABiosciences) for Breast Cancer (PAMM-131), Cancer Pathway Finder (PAMM033), Growth Factors (PAMM-041), and Inflammatory Cytokines and Receptors(PAMM-011). In addition to the arrays, primers for the following selected RNA were purchased from SABiosciences: Tnfs11 (RANKL) (PPM03047E), $18 S$ ribosomal RNA (rRNA) (PPM57735E), Ribosomal protein L32 (RPL32) (PPM03300B). For qRT-PCR analysis, each reaction $(25 \mu \mathrm{L})$ included $12.5 \mu \mathrm{L}$ of $2 \mathrm{X}$ SABiosciences $\mathrm{RT}^{2}$
qPCR Master Mix (SYBR Green), $1 \mu \mathrm{L}$ of diluted firststrand cDNA synthesis reaction, and $11.5 \mu \mathrm{L}$ of deionized $\mathrm{H}_{2} \mathrm{O}$. qRT-PCR was performed with the ABI 7500 Fast Real-Time PCR System (Applied Biosystems, Inc., Foster City, CA, USA) using the following program: step 1: $95^{\circ} \mathrm{C}, 10$ minutes; step 2: 40 cycles of $95^{\circ} \mathrm{C}$, $15 \mathrm{~s}$ and $60^{\circ} \mathrm{C}, 1$ minute; step 3: dissociation curve $95^{\circ} \mathrm{C}, 1$ minute; $65^{\circ} \mathrm{C}, 2$ minutes (optics off); 65 to $95^{\circ} \mathrm{C}$ at $2^{\circ} \mathrm{C}$ per minute (optics on). The data were analyzed using online software from SABiosciences [26]. For RANKL RNA, the comparative cycle threshold (CT) method was used to calculate the fold change in gene expression after normalization to the values for $18 S$ rRNA and RPL32 RNAs. RNA from the number 4-inguinal mammary glands of three animals was analyzed from each treatment group. In the tumor analysis, the three HFD-E tumors were adenosquamous (ER-), ductal $(E R+)$ and cribriform (ER-) adenocarcinomas with tumor onset at 10, 14 and 17 weeks post-DMBA, respectively. The three LFD tumors were adenosquamous (ER-), papillary (ER+) and cribriform (ER-) adenocarcinomas with tumor onset at 31, 34 and 38 weeks post-DMBA, respectively.

\section{Pathway analysis}

Genes that were significant (unadjusted $p$-value $<0.05$ ) in univariate analyses were evaluated for ontological enrichment using Ingenuity Pathway Analysis (IPA, Ingenuity ${ }^{\circ}$ Systems, Redwood City, CA, USA), with BenjaminiHochberg (B-H) multiple testing correction. The background was set to include only the genes on the qPCR arrays analyzed for each sample group. Significant functions and pathways were defined as those with at least two significant genes per pathway and with $\mathrm{B}-\mathrm{H} P$-values less than 0.05 .

\section{Analysis of plasma cytokine levels}

Plasma levels of 20 different cytokine proteins (AREG, basic fibroblast growth factor (bFGF), epidermal growth factor (EGF), hepatocyte growth factor (HGF), insulinlike growth factor 2 (IGF-2), IL-6, leptin, receptor activator of nuclear factor kappa-B ligand (RANKL), vascular endothelial growth factor (VEGF), resistin, TNF $\alpha, \mathrm{IL}-1 \alpha$, IL-1 $\beta$, insulin-like growth factor binding protein (IGFBP)2, IGFBP-3, prolactin, T-cell activation (TCA)-3 (CCL1), macrophage colony stimulating factor (M-CSF), epiregulin, and osteoprotegerin (OPG)) were determined by cytokine Ab arrays (Cat. number: AAM-CUS-G; RayBiotech, Norcross, GA, USA), following the manufacturer's instructions. Briefly, the glass array slide was incubated with blocking buffer for 30 minutes at RT, and then incubated with diluted mouse plasma $(30 \mu \mathrm{L}$ plasma diluted to $120 \mu \mathrm{L}$ with blocking buffer) overnight at $4^{\circ} \mathrm{C}$ with slow shaking. Then, after thorough washing with washing buffer, the array slide was incubated with biotin-labeled Ab 
for $2 \mathrm{~h}$ at RT with slow shaking. After thorough washing with washing buffer, the array slide was incubated with HiLytePlus $^{\mathrm{TM}} 555$ Fluor-conjugated streptavidin for $2 \mathrm{~h}$ at RT with slow shaking. Then, after thorough washing, the slide was dried and absolute fluorescent intensity measured by an Agilent G2505B laser scanner (Agilent Technologies, Inc., Santa Clara, CA, USA). The data were analyzed by software provided by the company. Additionally, plasma IGF-1 levels were measured using a mouse IGF-1 ELISA kit (ELM-IGFI-001; RayBiotech), according to the manufacturer's directions.

\section{Statistical analyses}

The PCR arrays were statistically analyzed using proprietary software from SABiosciences. Correlations between cytokine mRNA levels and leukocyte populations were determined by Spearman's method [27]. Otherwise, results are expressed as mean \pm standard error of the mean (SEM). Differences were considered significant at $P<0.05$ using the Student $t$-test or analysis of variance (ANOVA) followed by the Tukey multiple comparison test, as appropriate. Tumor incidence was analyzed by the Chi-square test. Tumor latencies were determined from Kaplan-Meier plots.

\section{Results}

\section{HFD decreases tumor latency}

A Kaplan-Meier plot (Figure 1A) shows that HFD-fed mice developed tumors significantly earlier than LFD- fed mice $(P=0.01)$ with a significantly reduced median time to tumor onset (204 days LFD versus 115 days HFD; $P=0.00075)$. Although HFD caused a 1.8-fold increase in tumor incidence (LFD, 14.95\%, $\mathrm{n}=87$ mice versus $H F D, 26.3 \%, \mathrm{n}=95$ mice; $P=0.059$ ), this did not reach statistical significance. Notably, there were no significant differences in body weight (see Additional file 2) or in parametrial fat pad weights (data not shown) between animals fed HFD and LFD over the course of the tumor study.

Since decreased latency was the major difference between the two diets, we focused on investigating the basis for the latency difference. To that end, we focused our analysis on comparing early developing tumors on HFD (HFD-E) tumors with LFD tumors. Representative HFD-E tumors were selected from tumors that developed before the earliest observed LFD tumors, at 19 weeks or less post-first DMBA treatment. Conversely, representative LFD tumors were selected after 19 weeks or more post-first DMBA treatment, when LFD tumors were first detected. We considered the possibility that reduced latency in HFD-fed mice might be due to accelerated development and increased numbers of atypical hyperplastic, pre-cancerous lesions. Time-course analysis showed that, indeed, HFD-fed mice developed significantly more hyperplastic lesions per mouse after 8 and 14 weeks post-first DMBA treatment (10 and 16 weeks on diet, respectively), times before palpable tumors were
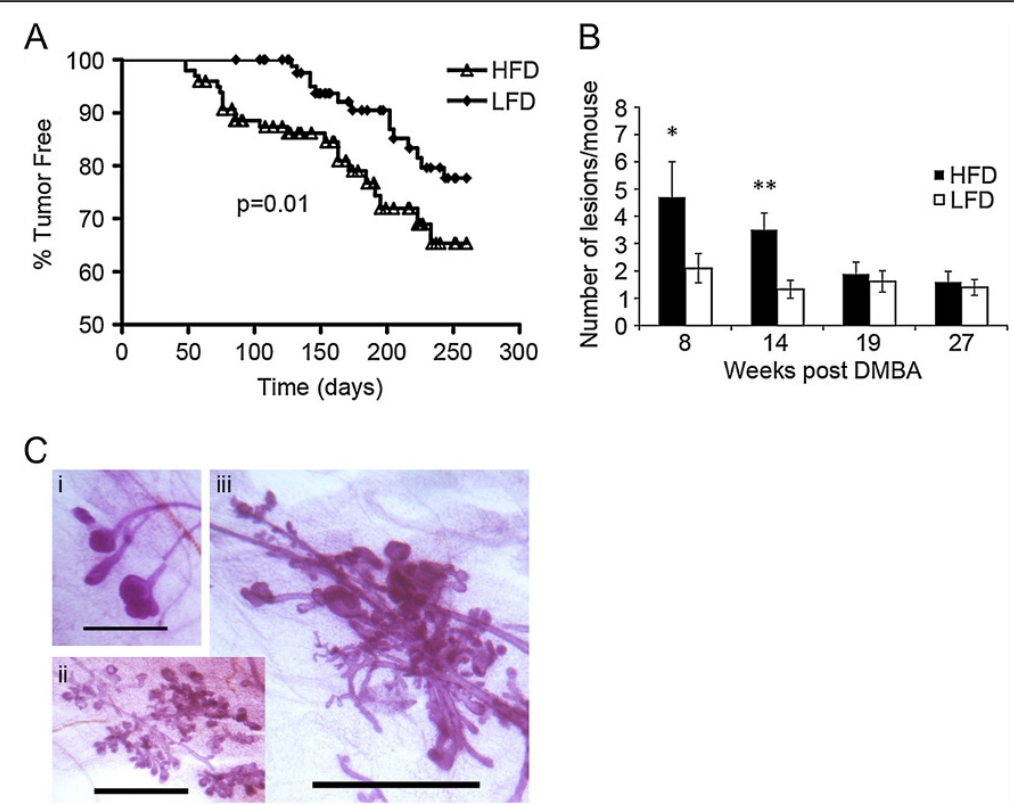

Figure 1 Characteristics of tumor development in high fat diet- versus low fat diet-fed mice. (A) Kaplan-Meier plot of all tumors developing in high fat diet (HFD)- and low fat diet (LFD)-fed mice. Time = number of days post last 7,12-dimethylbenz[a]anthracene (DMBA) treatment (HFD mice, $n=95$; LFD mice, $n=87$ ) (B) Time-course of epithelial proliferative lesion development. More hyperplastic and precancerous lesions developed in HFD-fed DMBA-treated mice at 8 and 14 weeks post first DMBA treatment. Bars represent mean \pm standard error of the mean of lesions per mouse; $n=5$ mice at each time for HFD and LFD. ${ }^{*} P=0.05 ;{ }^{* *} P=0.003$. (C) Epithelial proliferative lesions comprised (i) terminal duct hyperplasia, (ii) lobular hyperplasia, and (iii) mixed dysplasia. Scale bar $=1 \mathrm{~mm}$. 
Table 1 Tumor histopathology

\begin{tabular}{llll}
\hline Tumor & $\mathbf{N}$ & Adenocarcinoma type & ER status $^{\mathbf{a}}$ \\
\hline Low fat diet & 13 & 7/13 glandular/acinar & 7/13 ER+ \\
& & \\
& & \\
& & $3 / 13$ adenosquamous &
\end{tabular}

High fat diet-early $\quad 10 \quad 3 / 10$ glandular/acinar $\quad 6 / 10$ ER+

7/10 adenosquamous

${ }^{a}$ Estrogen receptor (ER) status based on $>10 \%$ receptor-positive cells. High fat diet-early represents mice with early developing tumors while on the high fat diet.

detected (Figure 1B). The hyperplastic lesions comprised ductal and alveolar hyperplasia for both diets (Figure 1C). There were no significant differences in tumor types or ER status (Table 1).

\section{Effects of diet on mammary gland and tumor proliferation}

We examined mammary epithelial cell and tumor cell proliferation, as determined by BrdU incorporation, at 10 weeks on diet and in tumors (Figure 2A). These measurements were compared to our earlier report of HFDenhanced proliferation at 4 weeks on diet [18]. At both 4 and 10 weeks on diet, there were significant increases in epithelial cell proliferation in HFD-fed mice, with the highest proliferation seen at 10 weeks in normal mammary structures and hyperplastic lesions. Proliferation was also significantly greater in HFD-E tumors, but was less than that seen after 10 weeks on HFD.

Since tissues and tumors require adequate vascularization to sustain proliferation, we also measured angiogenesis, as determined by blood vessel density (Figure 2B, C). At 3 and 4 weeks on diet, blood vessel density was low and independent of diet. At 10 weeks on diet, HFD-fed mice exhibited significantly increased blood vessel density around normal mammary gland structures and foci of atypical hyperplasia compared with LFD-fed mice. Notably, blood vessel density was highest around microscopic, nonpalpable tumors in HFD-fed mice. HFD-E tumors also exhibited increased blood vessel density.

To gain further insight into the enhanced proliferative characteristics observed on HFD, we analyzed RNA expression by qRT-PCR using PCR arrays targeted to Growth Factors (Table 2). At 3 weeks, Fgf18 and Il4 were upregulated, and at 4 weeks, brain derived neurotrophic factor (Bdnf) and leukemia inhibitory factor (Lif) were upregulated, whereas Lefty2 was downregulated. Interestingly, at 4 weeks on HFD, only $R A N K L$ was robustly upregulated 17 -fold. RANKL is a P-regulated paracrine growth factor in the mammary gland [28-30], and HFD-
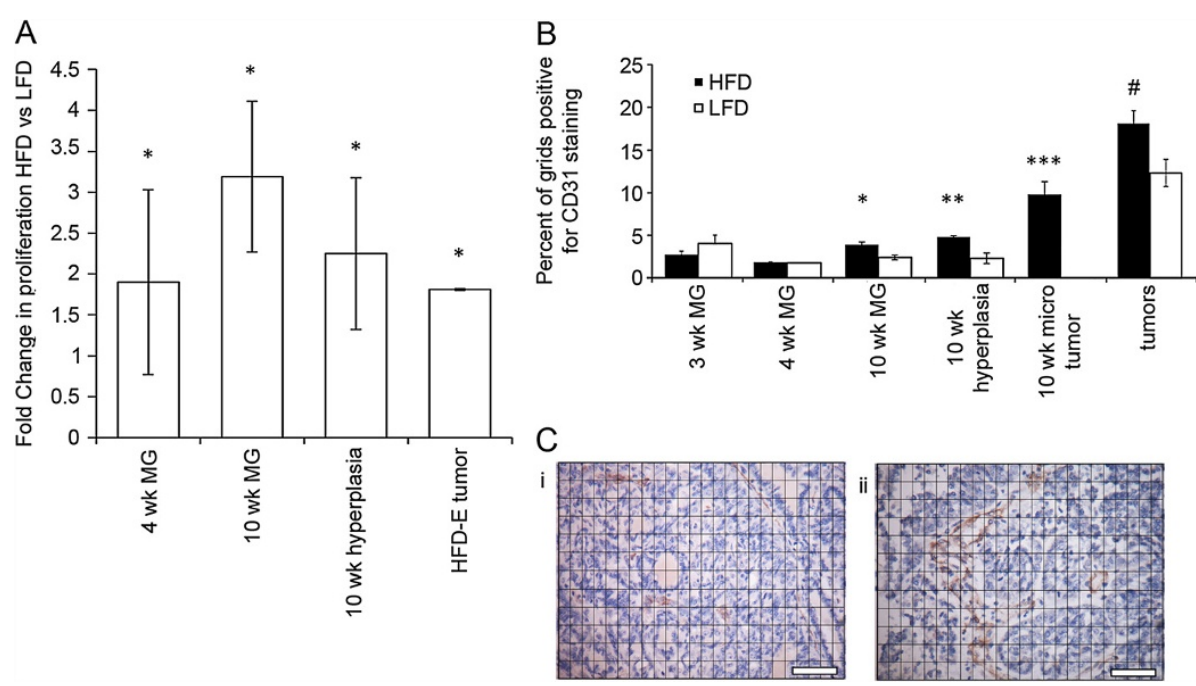

Figure 2 Proliferation and angiogenesis in mammary glands, tumors, and tumor microenvironments in mice fed on high fat and low fat diets. (A) Proliferation: fold increases in proliferation in normal mammary epithelium at 4 and 10 weeks, hyperplastic foci at 10 weeks, and in tumor epithelium from mice on a high fat diet (HFD) versus low fat diet (LFD). At 4 weeks, mice fed HFD exhibited increased cellular proliferation as measured by proliferating cell nuclear antigen (PCNA); ${ }^{*} P<0.05$. Note, the 4-week data are a re-analysis of data published in Olson et al. (2008). At 10 weeks, mice fed HFD exhibited increased cellular proliferation in both normal epithelium and hyperplastic foci, as measured by 5-bromo-2'deoxyuridine (BrdU) incorporation; ${ }^{*} P<0.05$. Early developing tumors on HFD (HFD-E) also exhibited increased cellular proliferation, as measured BrdU incorporation; ${ }^{*} P<0.05$. (B) Angiogenesis: blood vessel density was measured, as described in Materials and Methods, by the area occupied by CD31-positive vessels near normal mammary epithelium at 3,4, and 10 weeks, and in tumor epithelium from mice on HFD versus LFD. At 10 weeks, CD31-stained vessels were significantly increased adjacent to normal mammary gland structures $\left({ }^{*} P=0.01\right)$, hyperplastic foci $\left({ }^{* *} P=0.04\right)$ and microscopic tumors (tumors versus hyperplasia; ${ }^{* * *} P=0.02$ ) in HFD-fed compared to low fat diet (LFD)-fed mice. CD31 staining was also greater in HFD-E tumors ( $\#=0.01$ ) compared to LFD tumors. (C) Insets show increased CD31 staining of (ii) an HFD-E tumor compared with (i) an LFD tumor. Scale bars $=50 \mathrm{~mm}$. 
Table 2 Targeted Q-PCR analysis of mammary glands after 3, 4, or 10 weeks and mammary tumors on HFD versus LFD

\begin{tabular}{|c|c|c|c|c|c|}
\hline \multicolumn{2}{|c|}{ Growth factor genes } & \multicolumn{4}{|c|}{ Fold change HFD versus LFD } \\
\hline Symbol & Description & $\begin{array}{l}3 \text { wks } \\
\text { MG }\end{array}$ & $\begin{array}{l}4 \text { wks } \\
\text { MG }\end{array}$ & $\begin{array}{l}10 \text { wks } \\
\text { MG }\end{array}$ & Tumor \\
\hline Fgf18 & Fibroblast growth factor 18 & 2.0 & - & - & - \\
\hline 114 & Interleukin 4 & 2.0 & - & - & - \\
\hline Bdnf & $\begin{array}{l}\text { Brain derived neurotrophic } \\
\text { factor }\end{array}$ & - & 2.4 & - & - \\
\hline Lefty2 & $\begin{array}{l}\text { Left-right determination } \\
\text { factor } 2\end{array}$ & - & -2.5 & - & - \\
\hline Lif & Leukemia inhibitory factor & - & 2.8 & - & - \\
\hline RANKL & $\begin{array}{l}\text { Receptor activator of nuclear } \\
\text { factor kappa-B ligand }\end{array}$ & - & 17 & - & - \\
\hline Bmp2 & $\begin{array}{l}\text { Bone morphogenetic } \\
\text { protein } 2\end{array}$ & - & - & 2.0 & - \\
\hline Bmp3 & $\begin{array}{l}\text { Bone morphogenetic } \\
\text { protein } 3\end{array}$ & - & - & 2.4 & - \\
\hline Fgf10 & Fibroblast growth factor 10 & - & - & 2.0 & - \\
\hline Gdf10 & $\begin{array}{l}\text { Growth differentiation } \\
\text { factor } 10\end{array}$ & - & - & 1.9 & - \\
\hline Gdf5 & $\begin{array}{l}\text { Growth differentiation } \\
\text { factor } 5\end{array}$ & - & - & 2.2 & - \\
\hline Nodal & Nodal & - & - & 2.4 & - \\
\hline Pgf & Placental growth factor & - & - & 2.5 & - \\
\hline Tgfa & $\begin{array}{l}\text { Transforming growth } \\
\text { factor alpha }\end{array}$ & - & - & 1.9 & - \\
\hline$T g f b 1$ & $\begin{array}{l}\text { Transforming growth } \\
\text { factor, beta } 1\end{array}$ & - & - & 1.9 & - \\
\hline Vegfa & $\begin{array}{l}\text { Vascular endothelial } \\
\text { growth factor A }\end{array}$ & - & - & 2.1 & - \\
\hline $117 a$ & Interleukin 1 alpha & - & - & 3.0 & - \\
\hline $1 / 16$ & Interleukin 1 beta & - & - & 2.1 & - \\
\hline 112 & Interleukin 2 & - & - & 3.0 & - \\
\hline 117 & Interleukin 7 & - & - & 3.4 & - \\
\hline CxCl12 & $\begin{array}{l}\text { Chemokine (C-X-C motif) } \\
\text { ligand } 12\end{array}$ & - & - & 1.8 & - \\
\hline Bmp7 & $\begin{array}{l}\text { Bone morphogenetic } \\
\text { protein } 7\end{array}$ & - & - & - & 3.2 \\
\hline Inha & Inhibin alpha & - & - & - & 2.2 \\
\hline Ntf3 & Neurotrophin 3 & - & - & - & 53.4 \\
\hline Bmp10 & $\begin{array}{l}\text { Bone morphogenetic } \\
\text { protein } 10\end{array}$ & - & - & - & -3.4 \\
\hline
\end{tabular}

$\mathrm{N}=3$ high fat diet (HFD) mice, $\mathrm{n}=3$ low fat diet (LFD) mice, $\mathrm{n}=3$ HFD mice with early developing tumors (HFD-E), $\mathrm{n}=3$ LFD mice with tumors. $P \leq 0.05$ for all genes listed.

induced RANKL upregulation could contribute to the increased proliferation observed at 4 weeks on diet. There was no specific overlap in mammary gland gene expression at 3 or 4 weeks on diet.

At 10 weeks on diet, a large number of growth factor genes were upregulated in mammary glands of HFD-fed mice. The one with most obvious relevance to mammary epithelial proliferation was $T G F \alpha$ [31], a ligand for the EGF receptor (EGFR). Other upregulated genes included several encoding TGF $\beta$ superfamily growth factors [32] (that is, Bmp2, Bmp3, growth differentiation factor (Gdf) 5, Gdf10, Nodal, and Tgfb1), as well as genes encoding IL-2, IL-7, FGF10, PGF, VEGF-A, Chemokine (C-X-C motif) ligand (CXCL) 12, IL-1 $\alpha$, and IL- $1 \beta$. Interestingly, there was no specific overlap with growth factors found induced at 3 and 4 weeks on HFD.

Analysis of growth factor-related gene expression in the HFD-E tumors in comparison to LFD tumors showed upregulation of bone morphogenic protein (Bmp) 7, and inhibin $\alpha$ (Ihha), as well as a trend toward upregulation of Fgf15 $(P=0.09)$. Neurotrophin 3 (Ntf3) was most robustly upregulated (53-fold). Bmp10 was downregulated. It is striking that the HFD-E tumors display a unique gene expression profile that shows no overlap with the genes identified at 3,4 , and 10 weeks on diet.

\section{Effect of diet on inflammatory processes}

Leukocytes (that is, macrophages, eosinophils and mast cells) play important roles in normal pubertal mammary gland proliferation and development [9-11]. Since HFD promoted mammary epithelial cell proliferation, we also examined the effect of diet on leukocyte recruitment (Figure 3). At 3 weeks, there was a significant HFDinduced increase in recruitment of eosinophils to all mammary structures (Figure 3A) and of mast cells to large ducts (Figure 3B). At 4 weeks, this effect was no longer seen; however, high levels of eosinophils were observed around TEBs on both diets (Figure 3A). Macrophage recruitment to glandular structures was similar at 3 and 4 weeks, and was independent of diet (data not shown). The majority of macrophages were of the M2 phenotype (that is, Arg1+) for both diets.

At 10 weeks on diet, HFD-fed mice had significantly more macrophages recruited to all normal mammary gland structures (Figure $3 \mathrm{C}$ ). With both diets, the vast majority of recruited macrophages were M2-polarized. The greater number of macrophages recruited at 10 weeks on HFD did not appear to be due to an interaction with DMBA because the same fold increases in macrophages were detected at 10 weeks on HFD diet without DMBA treatment (data not shown). There were exceedingly low numbers of eosinophils and mast cells on either diet (data not shown). There were significantly more M2 macrophages present within HFD-E tumors and within their tumor stroma (Figure 3D). There were no significant differences in the numbers of eosinophils and mast cells associated with HFD-E or LFD tumors (data not shown).

To gain a better understanding of how HFD increased leukocyte recruitment, we compared the expression of inflammation-related genes in LFD and HFD mammary 

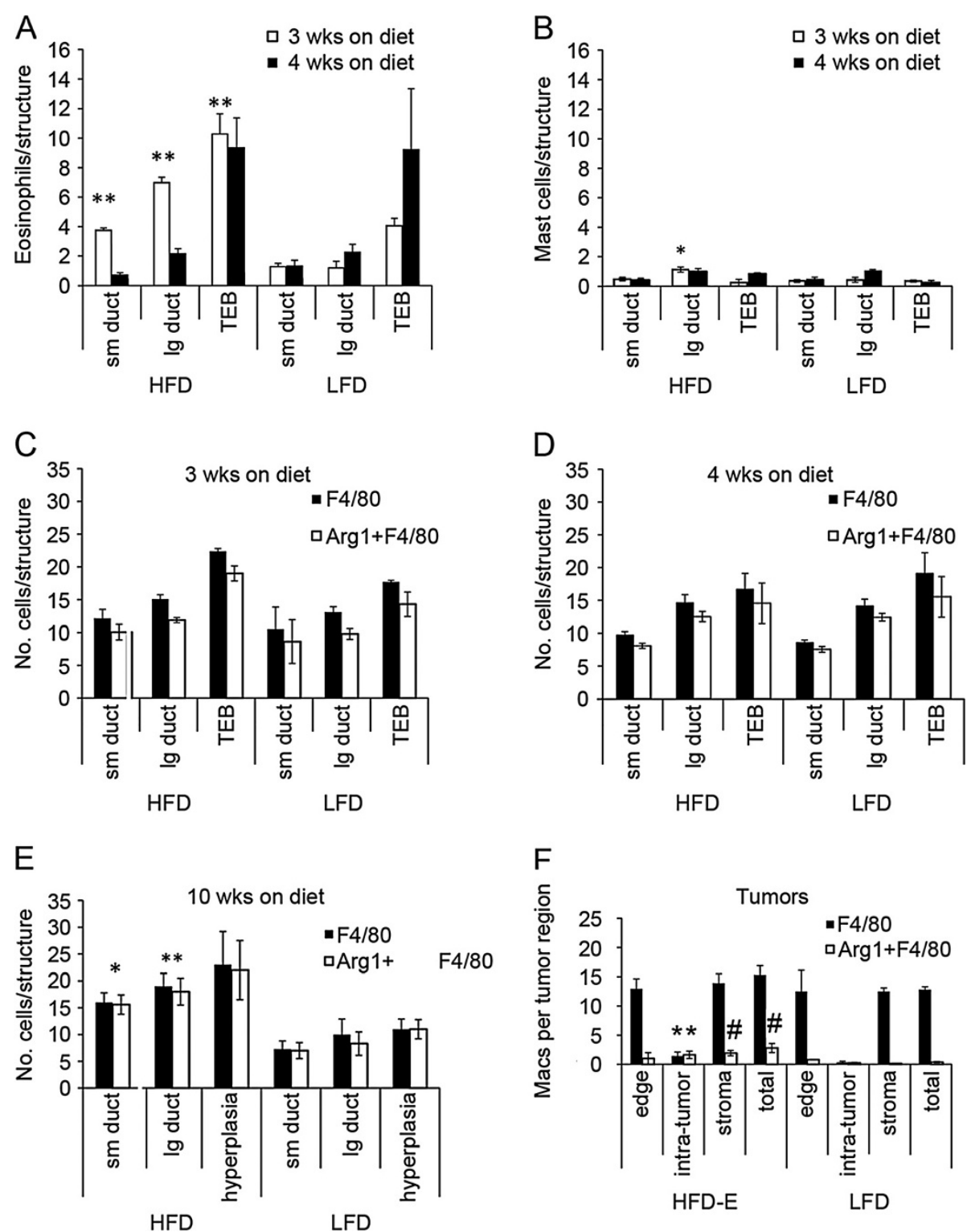

Figure 3 Inflammatory cell recruitment in mammary gland, tumors, and tumor microenvironments in high fat diet- and low fat dietfed mice. (A and B) BALB/C mice were started on diets at 3 weeks of age and terminated after 3 or 4 weeks for analysis of eosinophil (A) and mast cell (B) recruitment to mammary gland epithelial structures, as described in the Materials and Methods. At 3 weeks on diet, eosinophil recruitment (A) for all mammary structures and mast cell recruitment (B) for large ducts was significantly increased in high fat diet (HFD) compared to low fat diet (LFD)-fed mice. ${ }^{*} P=0.0001 ;{ }^{* *} P=0.03$. (C, D, E, and F) Sections from mice terminated at 3 weeks on diet (C), 4 weeks on diet (D), 10 weeks on diet (E) and from HFD-E and LFD tumors (F) were double immunofluorescently stained with anti-F4/80 and anti-Arg1 antibodies, as described in Materials and Methods, and then analyzed for macrophage recruitment. At 10 weeks, total macrophage (F4/80) and M2 macrophage (Arg1 + F4/80) recruitment $(\mathbf{E})$ was increased adjacent to small ducts ( $(P=0.01)$ and large ducts ( $\left.{ }^{* *} P=0.05\right)$ in mammary glands of HFD-fed mice. The increase in F4/80 and Arg1 + F4/80 staining in HFD versus LFD hyperplasia was not significant $(P=0.16)$. Tumor-associated macrophages (F) were quantified based on their location at the tumor edge, within the tumor (intra-tumor), in the tumor stroma (stroma), and combined for total tumor-associated macrophages. ${ }^{*} P=0.05$ that there were more F4/80 and Arg $1+F 4 / 80$ labeled macrophages within HFD-E tumors. ${ }^{*} P=0.01$ that there were more Arg1 + F4/80 macrophages (total) in HFD-E tumors and within HFD-E stroma.

glands by qRT-PCR using the Inflammatory Cytokines and Receptors PCR array (Table 3). There was no overlap in inflammation-related mRNA expressed at 3, 4, and 10 weeks on diet. Genes encoding CCL24 (eotaxin-2), CCL3 $(M I P-1 \alpha)$, IL-4, and IL5R $\alpha$ were transiently induced at 3 weeks. RANKL was the only upregulated inflammatory gene observed at 4 weeks.

At the 3- and 4-week diet time points, mice also had one inguinal mammary gland surgically cleared of endogenous mammary epithelium (cleared fat pad), whereas 
Table 3 Targeted qPCR analysis of mammary glands after 3,4 , or 10 weeks on HFD versus LFD

\begin{tabular}{|c|c|c|c|c|}
\hline \multicolumn{2}{|c|}{ Inflammation PCR array } & \multicolumn{3}{|c|}{$\begin{array}{l}\text { Fold change HFD } \\
\text { versus LFD }\end{array}$} \\
\hline Symbol & Description & $\begin{array}{l}3 \text { wks } \\
\text { MG }\end{array}$ & $\begin{array}{l}4 \text { wks } \\
\text { MG }\end{array}$ & $\begin{array}{c}10 \text { wks } \\
\text { MG }\end{array}$ \\
\hline $\mathrm{CCl} 24$ & Chemokine (C-C motif) ligand 24 & 2.7 & - & - \\
\hline $\mathrm{CCl} 3$ & Chemokine (C-C motif) ligand 3 & 2.3 & - & - \\
\hline 114 & Interleukin 4 & 2.2 & - & - \\
\hline $115 \mathrm{ra}$ & Interleukin 5 receptor, alpha & 3.0 & - & - \\
\hline RANKL & $\begin{array}{l}\text { Receptor activator of nuclear factor } \\
\text { kappa-B ligand }\end{array}$ & - & 17 & - \\
\hline $\mathrm{Ccl}$ & Chemokine (C-C motif) ligand 1 & - & - & 4.5 \\
\hline Ccl17 & Chemokine (C-C motif) ligand 17 & - & - & 3.2 \\
\hline Ccl19 & Chemokine (C-C motif) ligand 19 & - & - & 7.5 \\
\hline $\mathrm{CCl} 2 \mathrm{O}$ & Chemokine (C-C motif) ligand 20 & - & - & 5.2 \\
\hline $\mathrm{CCl} 22$ & Chemokine (C-C motif) ligand 22 & - & - & 7.6 \\
\hline 1116 & Interleukin 1 beta & - & - & 2.1 \\
\hline $112 r b$ & Interleukin 2 receptor, beta chain & - & - & 2.7 \\
\hline Cxcr2 & Chemokine (C-X-C motif) receptor 2 & - & - & 4.3 \\
\hline Lta & Lymphotoxin A & - & - & 3.2 \\
\hline Xcr1 & Chemokine (C motif) receptor 1 & - & - & 2.5 \\
\hline
\end{tabular}

$\mathrm{N}=3$ high fat diet (HFD) mice, $\mathrm{n}=3$ low fat diet (LFD) mice; $\mathrm{n}=3$ mice with early developing tumors while on HFD (HFD-E), $\mathrm{n}=3$ LFD mice with tumors. $P \leq 0.05$ for all genes listed.

the contralateral gland was kept intact (intact gland). This was done to identify effects that can be mediated in the fat pad independently of epithelial cells. Analysis of mammary gland inflammatory gene expression showed that upregulated genes only overlapped with that in intact glands for Il5ra at 3 weeks (Table 4). At 4 weeks, however, the cleared fat pads showed robust upregulation of Illf6 $(I l 36 \alpha)$ (6.5-fold) and Il1f8 (Il36 $\beta)$ (4.9-fold). These genes were not upregulated in intact glands.

Table 4 Targeted qPCR analysis of intact mammary glands and epithelium-devoid fat pads on HFD versus LFD

\begin{tabular}{ccccc}
\hline & \multicolumn{4}{c}{ Fold change HFD versus LFD } \\
\cline { 2 - 6 } Gene & $\mathbf{3}$ wks intact & $\mathbf{3}$ wks cleared & $\mathbf{4}$ wks intact & $\mathbf{4}$ wks cleared \\
\hline CCl24 & 2.7 & - & - & - \\
RANKL & - & - & 17.0 & - \\
CCI3 & 2.3 & - & - & - \\
$\| 4$ & 2.2 & - & - & - \\
$\| 5 \mathrm{ra}$ & 3.0 & 3.3 & - & - \\
$\| 1 f 6$ & - & - & - & 6.5 \\
$\| 178$ & - & - & - & 4.9 \\
\hline
\end{tabular}

$\mathrm{N}=3$ high fat diet (HFD) mice, $\mathrm{n}=3$ low fat diet (LFD) mice. $P \leq 0.05$ for all genes listed.
The Inflammatory Cytokines and Receptors PCR array identified 10 genes that were upregulated by HFD at 10 weeks on diet (Table 3 ). The upregulated genes were $I l 1 b, I l 2 r b$, lymphotoxin $\alpha$ (Lta), and a number encoding immune chemokines and chemokine receptors: chemokine (C-C motif) ligand $(\mathrm{Ccl})$ 1, Ccl17, Ccl19, Ccl20, Ccl22, chemokine (C-motif) receptor 1 (Xcr1), and chemokine ( $C-X-C$ motif) receptor $(\mathrm{Cxcr}) 2$. Similar to the Growth Factor gene analysis, there was no overlap between the genes found to be modulated at 3, 4, and 10 weeks on diet.

\section{Tumor characteristics}

To determine the properties of HFD-E tumors that could explain their reduced latency and their enhanced proliferative characteristics, we also analyzed RNA expression by qRT-PCR using Breast Cancer, and Cancer Pathway Finder PCR arrays. This analysis (Table 5) showed upregulation of cyclin D2 (Ccdn2), insulin-like growth factor 1 receptor (Ifg1r), telomerase reverse transcriptase (Tert), Slit2, and $\beta$-catenin (Ctnnb1) expression, whereas keratin 8 (Krt8) and keratin 18 (Krt18) were expressed at lower levels. Discordant with the protumorigenic properties of many genes upregulated in HFD-E tumors, several upregulated genes are known tumor suppressors (Brca2 [33], Slit2 [34], Trp53 [35], Apaf1 [36], and Brca1 [33]). Nonetheless, it is striking that the HFD-E tumors displayed a unique gene expression profile in comparison to LFD tumors.

Table 5 Targeted qPCR analysis comparing HFD-E tumors with LFD tumors

\begin{tabular}{llc}
\hline Breast cancer genes & $\begin{array}{c}\text { HFD-E versus LFD } \\
\text { tumor } \\
\text { Fymbold change }\end{array}$ \\
\cline { 1 - 2 } Brca2 & Description & 1.8 \\
Ccnd2 & Cyclin D2 & 3.5 \\
Igf1r & Insulin-like growth factor I receptor & 3.5 \\
Slit2 & Slit homolog 2 (Drosophila) & 2.9 \\
Trp53 & Transformation related protein 53 & 1.6 \\
Krt18 & Keratin 18 & -3.8 \\
Krt8 & Keratin 8 & -4.7 \\
& Cancer pathway finder genes & HFD-E versus LFD \\
& tumor \\
Apaf1 & Apoptotic peptidase activating factor 1 & 1.8 \\
Brca1 & Breast cancer 1 & 1.8 \\
Ctnnb1 & Catenin (cadherin associated protein), beta 1 & 1.8 \\
Tert & Telomerase reverse transcriptase & 1.9 \\
\hline
\end{tabular}

$\mathrm{N}=3$ mice with early developing tumors while on high fat diet (HFD-E), $\mathrm{n}=3$ low fat diet (LFD) mice with tumors. $P \leq 0.05$ for all genes listed. 
Table 6 Top canonical pathways of 3, 4, and 10 weeks on diet and tumor sample groups

\begin{tabular}{|c|c|c|c|c|}
\hline $\begin{array}{l}\text { qPCR } \\
\text { dataset }\end{array}$ & Ingenuity canonical pathways & $\begin{array}{l}\text { B-H-adjusted } \\
P \text {-value }\end{array}$ & Ratio & Molecules \\
\hline \multirow{3}{*}{3 weeks } & Communication between Innate and Adaptive Immune Cells & $9.11 \mathrm{E}-03$ & $2 / 109$ & CCL3L1/CCL3L3, IL4 \\
\hline & Granulocyte Adhesion and Diapedesis $^{a}$ & $9.33 \mathrm{E}-03^{\mathrm{a}}$ & $2 / 175^{\mathrm{a}}$ & CCL3L1/CCL3L3, CCL24 \\
\hline & Agranulocyte Adhesion and Diapedesis $^{\mathrm{a}}$ & $9.33 \mathrm{E}-03^{\mathrm{a}}$ & $2 / 186^{a}$ & CCL3L1/CCL3L3, CCL24 \\
\hline \multirow{5}{*}{4 weeks } & Human Embryonic Stem Cell Pluripotency & $1.44 \mathrm{E}-04$ & $3 / 156$ & BDNF, FZD5, LEFTY2 \\
\hline & Mouse Embryonic Stem Cell Pluripotency & 4.07E-03 & $2 / 99$ & LIF, FZD5 \\
\hline & $\begin{array}{l}\text { Role of NANOG in Mammalian Embryonic Stem Cell } \\
\text { Pluripotency }\end{array}$ & $4.07 \mathrm{E}-03^{\mathrm{a}}$ & $2 / 114^{a}$ & LIF, FZD5 \\
\hline & $\begin{array}{l}\text { Role of Osteoblasts, Osteoclasts and Chondrocytes in } \\
\text { Rheumatoid Arthritis }\end{array}$ & $1.20 \mathrm{E}-02$ & $2 / 238$ & TNFSF11, FZD5 \\
\hline & $\begin{array}{l}\text { Role of Macrophages, Fibroblasts and Endothelial Cells in } \\
\text { Rheumatoid Arthritis }\end{array}$ & $1.83 \mathrm{E}-02^{\mathrm{a}}$ & $2 / 332^{a}$ & TNFSF11, FZD5 \\
\hline \multirow{5}{*}{10 weeks } & Granulocyte Adhesion and Diapedesis $^{a}$ & $5.66 \mathrm{E}-09^{\mathrm{a}}$ & $8 / 166^{a}$ & $\begin{array}{l}\text { IL1A, CXCR2, CCL17, CCL20, IL1B, CCL22, } \\
\text { CCL19, CCL1 }\end{array}$ \\
\hline & Agranulocyte Adhesion and Diapedesis $^{a}$ & $5.66 \mathrm{E}-09^{\mathrm{a}}$ & $8 / 176^{a}$ & $\begin{array}{l}\text { IL1A, CXCR2, CCL17, CCL20, IL1B, CCL22, } \\
\text { CCL19, CCL1 }\end{array}$ \\
\hline & Hepatic Fibrosis / Hepatic Stellate Cell Activation & $1.55 \mathrm{E}-06$ & $6 / 140$ & VEGFA, IL1A, TGFB1, TGFA, IL1B, PGF \\
\hline & Altered T Cell and B Cell Signaling in Rheumatoid Arthritis & $3.24 \mathrm{E}-06$ & $5 / 86$ & IL1A, IL2, TGFB1, LTA, IL1B \\
\hline & $\begin{array}{l}\text { Role of Macrophages, Fibroblasts and Endothelial Cells in } \\
\text { Rheumatoid Arthritis }\end{array}$ & $3.32 \mathrm{E}-06^{\mathrm{a}}$ & $7 / 311^{\mathrm{a}}$ & VEGFA, IL1A, TGFB1, LTA, IL1B, IL7, PGF \\
\hline \multirow{5}{*}{ Tumor } & Molecular Mechanisms of Cancer & 7.10E-07 & $7 / 378$ & $\begin{array}{l}\text { TP53, CCND2, APAF1, BMP7, BRCA1, } \\
\text { CTNNB1, BMP10 }\end{array}$ \\
\hline & p53 Signaling & 7.10E-07 & $5 / 96$ & TP53, CCND2, APAF1, BRCA1, CTNNB1 \\
\hline & Basal Cell Carcinoma Signaling & $1.27 \mathrm{E}-05$ & $4 / 73$ & TP53, BMP7, CTNNB1, BMP10 \\
\hline & GADD45 Signaling & $1.43 \mathrm{E}-05$ & $3 / 22$ & TP53, CCND2, BRCA1 \\
\hline & $\begin{array}{l}\text { Role of NANOG in Mammalian Embryonic Stem Cell } \\
\text { Pluripotency }\end{array}$ & $4.54 \mathrm{E}-05^{\mathrm{a}}$ & $4 / 114^{\mathrm{a}}$ & TP53, BMP7, CTNNB1, BMP10 \\
\hline
\end{tabular}

${ }^{2}$ Pathways that are common between groups, with 10 weeks on diet, and tumor groups having an increased number of pathway molecules from 3 and 4 weeks on diet. B-H, Benjamini-Hochberg.

\section{Pathway analysis}

In ontology analyses (Table 6), few canonical pathways were altered at 3 weeks and 4 weeks, and among those pathways that met statistical significance criteria, few genes per pathway were significantly altered (see Additional files $7,8)$. By 10 weeks, a much broader range of genes were altered and several statistically significant pathways were identified, including Granulocyte and Agranulocyte Adhesion and Diapedesis $\left(P=5.66 \times 10^{-9}\right)$, Hepatic Fibrosis/Hepatic Stellate Cell Activation $\left(P=1.55 \times 10^{-6}\right)$, Altered T Cell and B Cell Signaling in Rheumatoid Arthritis $\left(P=3.24 \times 10^{-6}\right)$, and Role of Macrophages, Fibroblast and Endothelial Cells in Rheumatoid Arthritis $(P=3.32 \times$ $10^{-6}$ ) (see Additional file 9). The ontology analyses also identified several statistically significant pathways altered in the HFD-E tumors. These include Molecular Mechanisms of Cancer $\left(P=7.1 \times 10^{-7}\right)$, p53 Signaling $(P=7.1 \times$ $\left.10^{-7}\right)$, Basal Cell Carcinoma Signaling $\left(P=1.27 \times 10^{-5}\right)$, GADD45 Signaling $\left(P=1.43 \times 10^{-5}\right)$, and Role of NANOG in Mammalian Embryonic Cell Pluripotency $(P=4.54 \times$ $10^{-5}$ ) (see Additional file 10).
Dietary effects on metabolic parameters, hormone levels and systemic factors

As shown in Additional file 3, there were no major differences in non-fasting blood insulin or blood glucose levels at 10 weeks on LFD or HFD, or in HFD-E and LFD tumor-bearing mice. Mice fed LFD and HFD had glucose levels in the normal non-fasting range for $\mathrm{BALB} / \mathrm{c}$ mice $(<319 \mathrm{mg} / \mathrm{dL})$ (see Additional file 3: Figure S2A,C) [37]. Non-fasting serum insulin levels were similar at 10 weeks between LFD and HFD, with some values in the hyperinsulinemic range (normal non-fasting insulin $=0.77 \mathrm{ng} / \mathrm{mL}$ ) (see Additional file 3: Figure S2B) [37]. Insulin levels in HFD-E and LFD tumor-bearing mice varied widely and generally were in the hyperinsulinemic range (see Additional file 3: Figure S2D). The high insulin values were most likely indicative of some degree of insulin resistance. There were no differences in $\mathrm{E}$ or $\mathrm{P}$ levels at 4 or 10 weeks on HFD or LFD, or in tumor bearing mice (data not shown).

Plasma levels of additional growth and inflammatory factors were measured by $\mathrm{Ab}$ arrays to investigate 
potential systemic effects of HFD exposure (Table 7). At 4 weeks on HFD, the levels of OPG and IGF-1 were significantly elevated (1.3-fold, $P=0.04$ and 1.3-fold, $P=0.005$, respectively); this increase was transient and not seen at later time points, or in tumor-bearing mice. At 10 weeks on HFD, the only significantly modulated systemic protein was prolactin, of which there was decreased plasma expression (0.68-fold, $P=0.03)$. However, there was a trend toward increased IL- $1 \alpha$ levels (7.8-fold, $P=0.066)$. In HFD-E tumors, HGF was significantly increased (2.1-fold, $P=0.046)$. We compared mammary glands for mRNA expression of the factors detected in the plasma samples. The possible increase in systemic IL- $1 \alpha$ parallels the significant increase in mammary gland Illa RNA expression observed at 10 weeks on HFD (Table 3). Notably, mRNA encoding OPG, IGF-1, HGF, and prolactin were not detected at any time point in mammary gland or tumors, suggesting alternative systemic sources for their presence in plasma.

\section{Discussion}

In this study we have identified the effects of HFD started during puberty, to reduce the latency of DMBAinduced mammary cancers. Most notably, tumors that developed early (HFD-E) had important characteristics that differed from those of LFD tumors that developed significantly later. We identified the likely major contributors to HFD-induced decreased latency as local and systemically increased growth factor expression, and promotion of inflammatory and angiogenic processes. This occurred without causing significant body weight gain or obesity, and the metabolic effects of HFD on blood glucose and insulin levels were modest. It is particularly noteworthy that, although DMBA mutagenesis is virtually random in its targeting of genes in tumorigenesis, the tumors arising with short latency on HFD showed a unique gene expression profile, highlighting the potent overarching influence of HFD.

Table 7 Effect of diets on plasma levels of growth and inflammatory factors

\begin{tabular}{|c|c|c|c|}
\hline Serum factor & $\begin{array}{c}4 \text { wks on diet } \\
\text { HFD versus LFD } \\
\text { Fold change }\end{array}$ & $\begin{array}{c}10 \text { wks on diet } \\
\text { HFD versus LFD } \\
\text { Fold change }\end{array}$ & $\begin{array}{c}\text { Tumors } \\
\text { HFD-E versus LFD } \\
\text { Fold change }\end{array}$ \\
\hline HGF & - & - & 2.1 \\
\hline OPG & 1.3 & - & - \\
\hline $\mid G F-1$ & 1.3 & - & - \\
\hline prolactin & - & 0.68 & - \\
\hline
\end{tabular}

$\mathrm{N}=4$ mice on high fat diet (HFD) for 4 wks, $\mathrm{n}=4$ mice on low fat diet (LFD) for 4 wks; $n=4$ mice on HFD for 10 wks, $n=4$ mice on LFD for $10 w k s ; n=6$ HFD mice with early developing tumors (HFD-E), $n=6$ LFD mice with tumors. $P \leq 0.05$ for all genes listed.

\section{Proliferation}

We previously reported that pubertal BALB/c mice fed HFD for 4 weeks showed increased mammary epithelial cell proliferation [18]. Herein, we observed that HFD induced elevated mammary gland expression of several growth factor genes as early as 3 and 4 weeks on diet. In particular, $R A N K L$ was robustly induced at 4 weeks. RANKL is a P-induced paracrine factor that has known mitogenic activity in the mammary gland [38-40]. Plasma levels of OPG, a decoy receptor and RANKL antagonist [41], were also elevated at this time, and this may reflect a physiologic response to excess mammary RANKL levels. Additionally, plasma levels of IGF-1 were elevated at this time. Systemic IGF-1 and mammary gland expression of $R A N K L$ are plausible early sources of enhanced proliferation prior to the appearance of tumors in HFD-fed BALB/c mice [28-30,42,43]. IGF-1 is an essential growth factor for TEB formation [42] that has been implicated in breast cancer progression [43].

By 10 weeks on HFD, a time point prior to the appearance of palpable tumors, mammary glands showed increased numbers of abnormal mammary epithelial lesions, and enhanced cellular proliferation. Increased levels of the RNA encoding growth factors associated with mammary epithelial cell proliferation and development were detected. Perhaps most provocative among these was the gene encoding TGF $\alpha$, an EGFR ligand that has been associated with precocious alveologenesis, delayed involution, and mammary tumorigenesis [21]. Interestingly, it was recently reported that paracrine EGFR signaling between tumor-associated macrophages and murine breast cancer cells can promote a cancer stem cell-like phenotype [44]. Also provocative was the increased expression of a number of genes in the TGF- $\beta$ superfamily (Bmp2 and 3, Gdf5 and 10, Nodal, and Tgfb1) in HFD-fed mice. Signaling by TGF- $\beta 1$ family members mediate embryonic development, tissue homeostasis and regeneration, immune responses, tumor suppression, and metastasis, as well as govern the behavior of many stem cell populations [45-48]. TGF- $\beta 1$ has an established role in mammary gland ductal development [49-51]. The Nodal signaling pathway is activated by Cripto-1, which encodes a growth factor with a role in mammary gland development that is capable of inducing ductal hyperplasia [52]. Lefty2, which was downregulated at 4 weeks, functions as an antagonist of the Nodal pathway [53], and this earlier downregulation may set the stage for activation of Nodal signaling at 10 weeks. Specific roles for $B m p 3$ and Gdf10 in the mammary gland have not been reported. Increased Tert expression is also associated with the immortalization of cells, and as such, it antagonizes apoptosis [54]. This may also contribute to a proliferative phenotype. Indeed, 95\% of human cancers show increased Tert activity [55]. Upregulation of genes encoding IL-2 
and IL-7 has been associated with some classes of breast tumors [56,57]; these were also upregulated in mammary glands of 10-week HFD-fed mice.

Analysis of HFD-E tumor characteristics showed increased cellular proliferation that was associated with upregulation of genes that promote cellular proliferation such as Bmp7, Ccdn2, Inha, and Igf1r. BMPs are recognized as key regulators during the control of cell fate and cancer development [58], and BMP signaling can downregulate levels of mitotic checkpoint components in human breast cancer cells [59]. Bmp 7 has also been implicated in increasing the metastatic potential of $4 \mathrm{~T} 1$ mouse mammary tumor cells [60]. There was also a trend toward upregulation of $F g f 15(P=0.09)$. FGFs and their receptors control a wide range of biological functions operative in cancer including cellular proliferation [61]. On the other hand, Bmp10, which has been shown to decrease aggressiveness of breast cancer cells [62], was downregulated in HFD-E tumors. Thus, decreased Bmp10 expression is consistent with greater cellular proliferation of HFD-E tumors. Expression of IGF-1R is known to be increased in human breast cancers and associated with increased cellular proliferation [63-66]. Inhibins are growth factors that are also involved in cell proliferation and differentiation, and inhibin $\alpha$ is expressed in normal mammary tissues and in human breast cancers; however, its specific role in tumors is not well understood [67]. The increased expression of $C c d n 2$ is discordant with enhanced tumorigenesis of HFD-E tumors, as loss of cyclin D2 expression is frequent in breast cancers [68]. However, transgenic overexpression of cyclin D2 does block lobuloalveolar development [69] and, perhaps, $C c d n 2$ overexpression in our system could be viewed as suppressing differentiation.

Several genes that are activated in response to DNA damage (Brca1, Brca2, and Trp53) were upregulated in HFD-E tumors. Trp53 is a downstream target of Brca1 [70], and Apaf1, an important mediator of apoptosis that is a downstream target of $\operatorname{Trp53}$, is also upregulated [71]. Thus, the upregulation of these genes appears to constitute the upregulation of a pathway associated with DNA damage, perhaps resulting from exposure to the mutagenic carcinogen DMBA, rather than the coincident overexpression of several mutated tumor suppressor genes. It is plausible that $\operatorname{Trp} 53$ upregulation of Apaf1 is related to removal of damaged cells by apoptosis [71]. While DMBA treatment was dissociated in time from the occurrence of tumors, DMBA is known to induce aneuploidy and unstable karyotypes that might sustain DNA damage long after exposure [72]. Additionally, expression of $\mathrm{Krt} 8$ and 18, associated with more differentiated mammary luminal cells [73,74], was significantly decreased, suggesting a more aggressive phenotype of HFD-E tumors. In regard to increased Ctnnb1 expression, the
Wnt $/ \beta$ catenin pathway is involved in normal mammary gland proliferation and development, and associated with poor prognosis in breast cancer [75]. Elevated Ctnnb1 ( $\beta$-catenin) expression may activate this pathway.

HGF was elevated in the plasma of HFD-E tumorbearing mice, and may play a role in driving HFD-E tumor growth. HGF regulates multiple cellular processes that stimulate cell proliferation, invasion, and angiogenesis, both in the normal mammary gland [76] and in breast cancer [77]. HGF is generally produced locally within the mammary gland/mammary cancer and acts in a paracrine manner. However, no HFD-induced increase in mammary gland or tumor expression of HGF was observed in the present study. Recently, HGF serum levels were reported to be significantly elevated with increasing tumor stage in breast cancer patients, raising the possibility of alternate sites of HGF production [78].

The integrated overview of the various aforementioned genes that is provided by pathway analysis tends to support the notion that genotoxic stress has activated p53 and Gadd45 signaling, two pathways associated with DNA damage $[79,80]$. The altered expression of Trp53, Ccnd2, Apaf1, Brca1, and Ctnnb1 identified the p53 signaling and GADD45 signaling pathways to high significance. Provocatively, altered expression of a partially overlapping set of genes, Trp53, Bmp7, Ctnnb1, and Bmp10, identified the Basal Cell Carcinoma signaling and Role of NANOG in Mammalian Stem Cell Pluripotency pathways. This suggests similarity between the HFD-E tumors and breast tumors displaying stem and/ or progenitor cell characteristics, such as basal-like breast cancer [81]. The downregulation of luminal epithelial makers, Krt8 and 18, in HFD-E tumors is also consistent with this. Although several of the HFD-E tumors were ER-positive, basal-like breast cancers can express ER $\alpha$ [82]. Further, epidemiological studies have associated basal-like breast cancer with increased abdominal adiposity [83]; although HFD-E tumor-bearing animals were not obese, obesity was associated with HFD.

\section{Angiogenesis}

It is noteworthy that a number of genes associated with angiogenesis (Gdf5, Nodal, Pgf, Vegfa, and Cxcl12) were upregulated by HFD at 10 weeks, concomitant with the observation of increased vascularity in the mammary glands of HFD-fed mice. Nodal expression is significantly elevated in malignant human breast cancers versus benign breast disease [84] and has been associated with vasculogenic mimicry, defined as functional plasticity of aggressive cancer cells forming de novo vascular networks [85]. GDF5 has also been shown to have angiogenic properties [86]. PGF and VEGF-A, angiogenic proteins of the VEGF family, are upregulated mainly in 
pathologic conditions, such as breast cancer, and are associated with poor prognosis [87]. CXCL12, produced by stromal fibroblasts within invasive breast cancers, promotes angiogenesis [88] and has additionally been associated with increased macrophage density in tumors [89]. Coincident with the induction of the above mentioned genes associated with angiogenesis, analysis of plasma at this time revealed decreased prolactin levels. Prolactin is reported to have anti-angiogenic effects [90] and its reduced expression may promote angiogenesis.

HFD-E tumors also exhibited increased blood vessel density and genes associated with angiogenesis, such as Ntf3, Bmp10, and Slit2, were also differentially regulated in these tumors. In fact, Ntf3 was the most highly upregulated growth factor gene (53-fold). Neurotrophins and the neurotrophin receptor p75 are expressed in human breast cancers and are implicated in promoting angiogenesis, tumor growth, invasion, and resistance to apoptosis [91]. Interestingly, in mice fed 60\% HFD, neurotrophin expression is increased in the brain, suggesting its upregulation here in HFD-E tumors may also be diet-induced [92]. Further, we found that $B d n f$, another member of the neurotrophin family of growth factor genes [93], was robustly induced at 4 weeks on HFD, perhaps suggesting an association between this family of growth factors and HFD.

\section{Inflammatory processes}

The induction of Ccl24 (eotaxin-2) and Ccl3 (MIP-1 $\alpha)$ RNAs at 3 weeks was concomitant with influx of eosinophils into the mammary peri-epithelial compartment. Both CCL24 [94] and CCL3 [95] are potent chemoattractants for eosinophils. Il5ra RNA is also elevated at this time; IL-5 is a differentiation factor for eosinophil progenitors [96]. Consistent with chemotaxis of eosinophils to adipose tissue, upregulation of Il4 RNA has also been observed [97]. Ccl24, Ccl3, and Il4 mRNAs all had high correlation with the level of eosinophils at 3 weeks on diet (Ccl24: $r=0.865$ to 0.886; Ccl3: $r=0.667$ to 0.812; Il4: $r=0.714$ to 0.943 (depending upon mammary structural element); see Additional file 11). The induction of Il4 RNA has potentially important implications for the function of macrophages in the mammary gland, as eosinophil-derived IL- 4 is essential for the maintenance of alternatively activated (that is, M2) macrophages in adipose tissue [97]. This is consistent with the high numbers of $\mathrm{Arg}^{+}$macrophages observed in the peri-epithelial stroma of the normal gland at 3 and 4 weeks on diet, and in the vicinity of early lesions and within tumors in DMBA/HFD-treated mice. While pathway analysis did not identify any canonical pathways to a high level of significance, chemotaxis of eosinophils was identified as a highly significant function $\left(P=6.4 \times 10^{-5}\right)$ (see Additional file 7$)$, and eosinophil levels correlated well with RNAs for all of the aforementioned chemokines and cytokine (see Additional file 11). Another inflammatory growth factor RNA increased in mice at 4 weeks was that encoding RANKL, a potent activator of NF-kB [98]. Thus, RANKL may play a role in the upregulation of pro-inflammatory factors at this time. In parallel to the analysis of whole intact mammary gland at 3 and 4 weeks of diet, a similar analysis of epithelium-devoid fat pads contralateral to the intact mammary glands was carried out. At 3 weeks, this revealed that Il5ra was similarly induced by HFD in both cleared fat pads and intact glands, suggesting that it is, in fact, associated with the stroma. At 4 weeks, this analysis also revealed HFD induction of the genes encoding IL-1f6 (IL-36 $\alpha$ ) and IL-1f8 (IL-36 $\beta$ ), IL-1 family cytokines known to be expressed in adipocytes as inflammatory mediators [99]. This induction is not observed in intact glands. It may be that the mammary epithelium suppresses this induction in intact glands, or, alternatively, that the stromal induction of these cytokines is obscured in the intact gland by dilution or because the same cytokines are downregulated in the epithelium, while being upregulated in the stroma. This highlights the mammary stroma as an epitheliumindependent source of inflammatory factors that can mediate the effects of HFD.

At 10 weeks on diet, the RNA encoding a number of cytokines and chemokines associated with immune function were modulated by HFD, and these may have profound implications for the status of the immune system at this point in time. Most interesting are the genes encoding the chemokines CCL1, CCL17, and CCL22, as well as the cytokine TGF- $\beta 1$, which are all associated with the recruitment and function of immunosuppressive Treg cells [100-102]. There is also one report of CCL20 recruiting Treg cells in an induced colorectal cancer model [103]. Further, these factors are all products of M2 macrophages, recruitment of which was induced by HFD at 10 weeks of diet. In fact, TGF- $\beta 1$ additionally can function in the generation of immunosuppressive M2 macrophages [104], perhaps, in part, through the suppression of M1 macrophage activity [105]. Upregulation of Ccl19, Ccl20 and chemokine (C-X$C$ motif) receptor $(C x c r) 2$ has also been associated with breast tumor growth and invasion [106-108], Cxcr2 particularly with angiogenic processes [108]. Systemic levels of prolactin were also reduced at 10 weeks on HFD. As prolactin can suppress the function of suppressor $\mathrm{T}$ cells [109], a decrease in its expression would be expected to enhance Treg activity. Indeed, increased numbers of Treg cells have been associated with increased DMBA-induced mammary carcinogenesis in mice [110], suggesting the importance of Treg-associated chemokines in this experimental system. Characterization of the influence of dietary fat upon $\mathrm{T}$ cell populations awaits future studies. 
Pathway analysis comparing mice on HFD to those on LFD at week 10 identified Granulocyte and Agranulocyte Adhesion and Diapedesis (identified by Illa, Cxcr2, Ccl17, Ccl20, Il1b, Ccl22, Ccl19, and Ccl1), which is consistent with leukocyte migration into the mammary gland. Furthermore, immune cell trafficking (adhesion of immune cells and leukocyte migration) was among functions showing the highest significance at 10 weeks on HFD $\left(P=1.64 \times 10^{-13}\right.$ and $2.03 \times 10^{-13}$, respectively $)$. Pathway analysis also identified Altered $\mathrm{T}$ Cell and $\mathrm{B}$ Cell Signaling in Rheumatoid Arthritis (identified by altered expression of $I l 1 a, I l 2, T g f b 1, L t a$, and $I l 1 b$ ) and Role of Macrophages, Fibroblasts and Endothelial cells in Rheumatoid Arthritis (identified by altered expression of Vegfa, Illa, Tgfb1, Lta, Il1b, Il7, and Pgf) (see Additional file 9), pathways that can lead to macrophagemediated pathology [111] and abnormal angiogenesis [112]. The identification of the Hepatic Fibrosis/Hepatic Stellate Cell Activation pathway (identified by Vegfa, $I l 1 a, T g f b 1, T g f a, I l 1 b$, and $P g f$ ) is interesting, as the polarization of M2 macrophages is a critical component of this pathology [113]. The levels of RNA encoding IL$1 \mathrm{~b}$, a common factor in all of these pathways, correlated well with the level of macrophages in the mammary gland ( $r=0.828$ to 0.886 (depending upon mammary structural element); see Additional file 11) suggesting the plausibility that these pathways may operate, at least in part, through macrophage recruitment. The genes included on the PCR arrays were highly selected for genes with established involvement in particular pathways (that is, growth factors, inflammation). Thus, it is also noteworthy to observe that the absolute number of significant genes on each targeted pathway array increased between week 4 and week 10 (Figure 4). The parallel increase in expression of inflammation and growth factor genes underscores that immune infiltrates can alter the expression of cytokines with regulatory effects on mammary epithelial proliferation.

The status of inflammatory processes also differed in HFD-E tumors compared to LFD tumors. There was a significant increase in intra-tumoral and stromal alternatively activated M2 (Arg1+) macrophages. The M2 phenotype is associated with tumor-associated macrophages that are known to promote the growth of tumors through support of angiogenic and tissue remodeling processes, as well as immune suppression [114]. The increase in M2 macrophages is consistent with the enhanced vascularity of HFD-E tumors in comparison to LFD tumors. While none of the cytokines identified as expressed in HFD-E tumors is known to generate M2 macrophages, Il4 is upregulated at 3 weeks and $T g f b 1$ is upregulated at 10 weeks on HFD, and these cytokines may be involved in the prior polarization of M2 macrophages [104]. There is compelling evidence at the molecular level that many cancers,

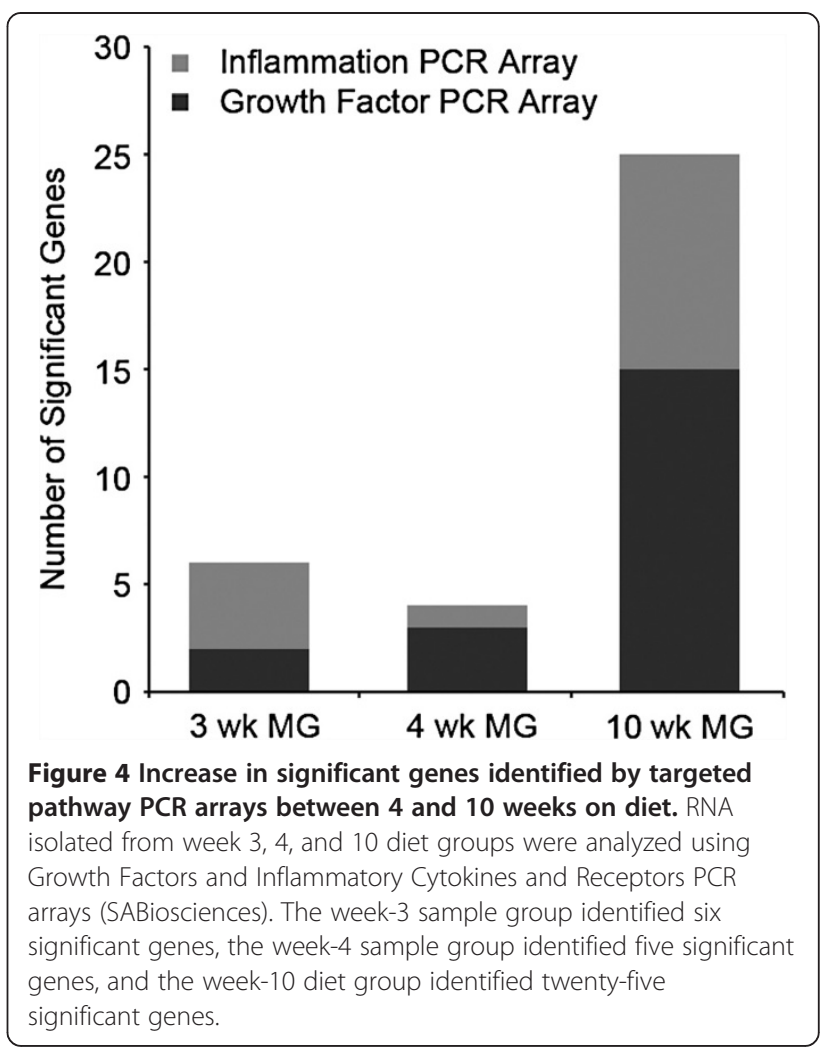

including breast cancer, are linked to a dysregulated inflammatory response [115]. The present results that demonstrate HFD-induced inflammatory processes involving M2 macrophages are consistent with a role for these macrophages and their secreted chemokines/cytokines in the promotion of HFD-E tumors.

As for the role of HFD, there is evidence that it can induce low-grade inflammation after feeding [116]. It has been proposed that HFD induces post-prandial gut permeability allowing low levels of bacterial endotoxin from the gut to enter the circulation and, thus, induce lowgrade inflammation [116,117]. There is also evidence that saturated fatty acids can directly modulate inflammatory processes through toll-like receptor 4 (TLR4) [118]. Palmitic acid, an abundant component of lard [119], has particularly been implicated in TLR2 $[120,121]$ and TLR4 signaling [120-123]. This stimulation has been associated with increased IL-1 signaling [120]. This is consistent with our observation of increased levels of $I l 1 a$ and $I l 1 b$ gene expression after 10 weeks on HFD.

\section{Systemic metabolic effects of HFD}

The levels of metabolism-related factors such glucose, insulin, leptin, and resistin were not significantly altered by HFD. However, an inflammatory growth factor RNA that increased in HFD mice at 4 weeks was that 
encoding LIF, an IL-6-class cytokine that can stimulate lipolysis and fat loss [124-126]. This places LIF as a plausible mediator contributing to the lack of weight gain in BALB/c mice placed on HFD. At 10 weeks on HFD, plasma IL- $1 \alpha$ levels were increased. Since HFD also increased mammary gland IL- $1 \alpha$ mRNA expression at 10 weeks, increased plasma levels might reflect spillover from the mammary gland or other tissues affected by HFD. Palmitic acid has been associated with increased IL-1 signaling [120], and elevation of serum IL$1 \alpha$ has been reported in HFD-induced obesity in mice [127]. Tumors showed a trend toward increased Fgf15 expression. FGF15-specific signaling is thought to control metabolic homeostasis associated with HFD to restore glucose tolerance and insulin sensitivity [128].

Other studies of the effect of dietary fat on normal mammary gland development and tumorigenesis have been carried out in rodents [129-131]. However, they differ significantly from the current studies with regard to species studied (rat versus mouse), differences in fat formulations (corn oil versus lard), caloric content (isocaloric versus non-isocaloric), obesogenic versus non-obesogenic outcomes, development of metabolic syndrome, and age at diet initiation. More similar studies on the effect of HFD on tumor development without the confounding effects of obesity have been performed in other mouse mammary cancer models. Results vary by tumor model and age at diet initiation. In two studies of the effects of HFD initiated at 4 weeks of age in mice overexpressing HER2/Neu in the mammary gland $[14,15]$, HFD promoted tumor development by increasing tumor incidence, but without increasing tumor cell proliferation; there was only a small increase in body weight and no insulin resistance or hyperinsulinemia. In another study, HER2/Neu transgenic mice fed HFD starting in adulthood, at 10 weeks of age, showed no difference in tumor latency, incidence, or metastasis [132]. In a tumor transplant model, mice were started on HFD at 4 weeks of age, and after 16 weeks on diet, 4 T1 mammary carcinoma cells were transplanted into their mammary glands [133]. There were only slight increases in body weight with HFD. However, tumor weight and number of metastases were significantly increased by HFD. Thus, based on the results of the present study and of the previous studies of HFD initiated in pubertal mice (4 weeks of age), there was a significant promotional effect on tumor development with only a modest effect on weight gain or metabolic parameters. This is in contrast to the lack of a promotional effect of HFD when initiated in adult, 10-week-old mice. The most extensive study was carried out in the $4 \mathrm{~T} 1$ tumor transplant model with diet started at 4 weeks of age [133]. Similar to our present results, that study revealed an association of HFD with increased macrophage infiltration, angiogenesis, and cellular proliferation, as well as increased levels of a number of inflammatory factors.

\section{Conclusions}

Taken together, our results demonstrate that exposure to HFD in the peri-pubertal period, and the sensitivity of the pubertal gland to HFD, initiate a sequence of inflammatory, angiogenic, and growth-promoting effects starting as early as 3 weeks on diet, which can lead to the promotion of mammary cancer development in adulthood. Notably, the observed effects of HFD were independent of significant weight gain. Importantly, this indicates a potential risk from HFD for a broader segment of the population than only those who become obese. The observation of a distinct expression profile associated with the HFD-dependent shorter latency of DMBA tumors highlights the potent influence of HFD in the context of a virtually randomly targeted carcinogen. It is also particularly noteworthy that, in our DMBA model and other tumor models, there is significant promotion of tumorigenesis under the potent influence of HFD. Future studies are needed to identify the specific effects of exposure to HFD at puberty versus adulthood, as well as to identify the mechanistic basis for dietary fat effects and potential interventions to prevent the promotional consequences of HFD exposure.

\section{Additional files}

Additional file 1: Table S1. Diet formulations

Additional file 2: Figure S1. Comparison of weight gains on Diets I and II. BALB/C mice were started on high fat diet (HFD) and low fat diet (LFD) I or II at 3 weeks of age and continued until 45 weeks of age. There were virtually identical weight gains on both diets. The dips in weight between 6 and 9 weeks were due to the response to 7,12-dimethylbenz (a)anthracene (DMBA) treatments.

Additional file 3: Figure S2. Comparison of the effects of Diets I and II on non-fasting blood levels of glucose and insulin. BALB/c mice were started on high fat diet (HFD) or low fat diet (LFD) I or II at 3 weeks of age. Blood levels of $(\mathbf{A}, \mathbf{C})$ glucose and $(\mathbf{B}, \mathbf{D})$ insulin were measured at 10 weeks on diet $(\mathbf{A}, \mathbf{B})$ or in tumor-bearing mice $(\mathbf{C}, \mathbf{D})$. The bars represent the mean \pm standard error of the mean for samples from five animals per diet at 10 weeks on diet, six early developing tumors on HFD (HFD-E), and five LFD tumor-bearing mice. ${ }^{*} P=0.02$ HFDIl blood glucose level higher than LFD II at 10 weeks on diet.

Additional file 4: Figure S3. Comparison of the effects of diets I (A) and II (B) on time-course of tumor development. Tumor development was monitored starting after the last 7,12-dimethylbenz(a)anthracene (DMBA) treatment. Kaplan-Meier plots show no significant differences in latency of tumors developing on (A) low fat diet (LFD) I versus LFD || or (B) high fat diet (HFD) I versus HFD II. Development of tumors in LFD-fed mice was observed only after 18 weeks post-DMBA treatment on either diet I or II. Time $=$ days post last DMBA treatment.

Additional file 5: Table S2. Tumor incidence.

Additional file 6: Figure S4. Diagram of experimental design. Additional file 7: Table S3. Three weeks on diet qPCR Ingenuity Pathway Analysis. 
Additional file 8: Table S4. Four weeks on diet GPCR Ingenuity Pathway Analysis.

Additional file 9: Table S5. Ten weeks on diet qPCR Ingenuity Pathway Analysis.

Additional file 10: Table S6. Tumor qPCR Ingenuity Pathway Analysis. Additional file 11: Figure S5. Correlations between cytokine mRNA expression and leukocyte recruitment. Cycle threshold $(\mathrm{Ct})$ values for the indicated $\mathrm{mRNA}$ in individual animals were normalized to the average $\mathrm{Ct}$ values for GusB, Hprt1, Hsp90ab1, Gapdh, and Actb mRNA in the same animals, and plotted against the indicated leukocyte counts in the same animals in association with the indicated individual structures.

Correlations ( $r)$ were calculated by Spearman's method.

\section{Abbreviations}

Ab: Antibody; ANOVA: Analysis of variance; Areg: Amphiregulin;

Arg1: Arginase 1; B-H: Benjamini-Hochberg; BMI: Body mass index; BMP: Bone morphogenetic protein; BrdU: 5-bromo-2'-deoxyuridine; BSA: Bovine serum albumin; CCl: Chemokine (C-C motif) ligand; Cxcl: chemokine (C-X-C motif) ligand; DAB: 3,3-diaminobenzidine; DAPI: 4,6-diamidino-2-phenylindole; DMBA: 7,12-dimethylbenz(a)anthracene; E: Estrogen; EGFR: Epidermal growth factor receptor; ELISA: Enzyme-linked immunosorbent assay; ER: Estrogen receptor; FGF: Fibroblast growth factor; GDF: Growth differentiation factor; $\mathrm{H}_{2} \mathrm{O}$ : Water; $\mathrm{H}_{2} \mathrm{O}_{2}$ : Hydrogen peroxide; H\&E: Hematoxylin and eosin; HFD: High fat diet; HFD-E: Early developing tumors on high fat diet; HGF: Hepatocyte growth factor; IgG: Immunoglobulin G; IL: Interleukin; LFD: Low fat diet; LIF: Leukemia inhibitory factor; MG: Mammary gland; OPG: Osteoprotegerin; P: Progesterone; PBS: Phosphate-buffered saline; PBSA $1 \%$ bovine serum albumin in phosphate-buffered saline; PCR: Polymerase chain reaction; psi: Pounds per square inch; qRT-PCR: Quantitative reverse transcription-polymerase chain reaction; RANKL: Receptor activator of nuclear factor kappa-B ligand; RT: Room temperature; SEM: Standard error of the mean; TEB: Terminal end bud; TGF: Transforming growth factor; TLR: Toll-like receptor; TNF: Tumor necrosis factor; Treg: Regulatory T cell; VEGF: Vascular endothelial growth factor.

\section{Competing interests}

The authors declare that they have no competing interests.

\section{Authors' contributions}

YZ and YST carried out the majority of the experiments. MDA carried out experiments and assisted in writing the manuscript. IML performed the histopathological analysis of the tumors. ELK and MAT contributed to pathway analysis and interpretation of gene expression analyses. RCS and $\mathrm{SZH}$ conceived and designed the study, interpreted the results and wrote the manuscript. All authors read and approved the final manuscript.

\section{Acknowledgements}

This work was supported by the Breast Cancer and the Environment Research Program Grants U01ES012800, UO1ESO19434 and U01ES019472 from the National Institute of Environment Health Science (NIEHS) and the National Cancer Institute ( $\mathrm{NCl}), \mathrm{NIH}, \mathrm{DHHS}$. Its contents are solely the responsibility of the authors and do not necessarily represent the official views of $\mathrm{NIEHS}, \mathrm{NCl}$, or $\mathrm{NIH}$. We also gratefully acknowledge support from the Avon Foundation, the Ladies Auxiliary to the Veterans of Foreign Wars, and the Helen L. Kay Charitable Trust for this research.

\section{Author details}

'Breast Cancer and the Environment Research Program, Department of Physiology, Michigan State University, East Lansing, MI 48824, USA. ${ }^{2}$ Department of Microbiology and Molecular Genetics, Breast Cancer and the Environment Research Program, Michigan State University, East Lansing, MI 48824, USA. ${ }^{3}$ Department of Pathobiology and Diagnostic Investigation, Michigan State University, East Lansing, MI, USA. ${ }^{4}$ Department of Epidemiology, Lineberger Comprehensive Cancer Center, University of North Carolina at Chapel Hill, Chapel Hill, NC, USA. ${ }^{5}$ Department of Pathology and Laboratory Medicine, Lineberger Comprehensive Cancer Center, University of North Carolina at Chapel Hill, Chapel Hill, NC, USA. ${ }^{6}$ Department of Physiology, Biomedical and Physical Sciences Building, Room 2201, 567 Wilson Road, Michigan State University, East Lansing, Ml 48824, USA.
Received: 1 March 2013 Accepted: 11 October 2013

Published: 25 October 2013

\section{References}

1. van den Brandt PA, Spiegelman D, Yaun SS, Adami HO, Beeson L, Folsom AR, Fraser G, Goldbohm RA, Graham S, Kushi L, Marshall JR, Miller AB, Rohan T, Smith-Warner SA, Speizer FE, Willett WC, Wolk A, Hunter DJ: Pooled analysis of prospective cohort studies on height, weight, and breast cancer risk. Am J Epidemiol 2000, 152:514-527.

2. Vrieling A, Buck K, Kaaks R, Chang-Claude J: Adult weight gain in relation to breast cancer risk by estrogen and progesterone receptor status: a meta-analysis. Breast Cancer Res Treat 2010, 123:641-649.

3. Park SY, Kolonel LN, Henderson BE, Wilkens LR: Dietary fat and breast cancer in postmenopausal women according to ethnicity and hormone receptor status: the Multiethnic Cohort Study. Cancer Prev Res (Phila) 2012, 5:216-228.

4. Berkey CS, Frazier AL, Gardner JD, Colditz GA: Adolescence and breast carcinoma risk. Cancer 1999, 85:2400-2409.

5. Hiatt RA, Haslam SZ, Osuch J: The breast cancer and the environment research centers: transdisciplinary research on the role of the environment in breast cancer etiology. Environ Health Perspect 2009, 117:1814-1822.

6. Pischon T, Nothlings U, Boeing H: Obesity and cancer. Proc Nutr Soc 2008, 67:128-145.

7. Ciarloni L, Mallepell S, Brisken C: Amphiregulin is an essential mediator of estrogen receptor alpha function in mammary gland development. Proc Natl Acad Sci USA 2007, 104:5455-5460.

8. Sternlicht MD, Sunnarborg SW: The ADAM17-amphiregulin-EGFR axis in mammary development and cancer. J Mammary Gland Biol Neoplasia 2008, 13:181-194.

9. Gouon-Evans V, Lin EY, Pollard JW: Requirement of macrophages and eosinophils and their cytokines/chemokines for mammary gland development. Breast Cancer Res 2002, 4:155-164.

10. Lewis CE, Pollard JW: Distinct role of macrophages in different tumor microenvironments. Cancer Res 2006, 66:605-612.

11. Lilla JN, Werb Z: Mast cells contribute to the stromal microenvironment in mammary gland branching morphogenesis. Dev Biol 2010, 337:124-133.

12. Calogero RA, Cordero F, Forni G, Cavallo F: Inflammation and breast cancer. Inflammatory component of mammary carcinogenesis in ErbB2 transgenic mice. Breast Cancer Res 2007, 9:211.

13. Lin EY, Jones JG, Li P, Zhu L, Whitney KD, Muller WJ, Pollard JW: Progression to malignancy in the polyoma middle T oncoprotein mouse breast cancer model provides a reliable model for human diseases. Am J Pathol 2003, 163:2113-2126.

14. Dogan S, Hu X, Zhang Y, Maihle NJ, Grande JP, Cleary MP: Effects of highfat diet and/or body weight on mammary tumor leptin and apoptosis signaling pathways in MMTV-TGF-alpha mice. Breast Cancer Res 2007, 9:R91.

15. Khalid S, Hwang D, Babichev Y, Kolli R, Altamentova S, Koren S, Goodwin PJ, Ennis M, Pollak M, Sonenberg N, Fantus IG: Evidence for a tumor promoting effect of high-fat diet independent of insulin resistance in HER2/Neu mammary carcinogenesis. Breast Cancer Res Treat 2010, 122:647-659.

16. Sieri S, Krogh V, Ferrari P, Berrino F, Pala V, Thiebaut AC, Tjonneland A, Olsen A, Overvad K, Jakobsen MU, Clavel-Chapelon F, Chajes V, Boutron-Ruault MC, Kaaks R, Linseisen J, Boeing H, Nöthlings U, Trichopoulou A, Naska A, Lagiou P, Panico S, Palli D, Vineis P, Tumino R, Lund E, Kumle M, Skeie G, González CA, Ardanaz E, Amiano P, et al: Dietary fat and breast cancer risk in the European Prospective Investigation into Cancer and Nutrition. Am J Clin Nutr 2008, 88:1304-1312.

17. Thiebaut AC, Kipnis V, Chang SC, Subar AF, Thompson FE, Rosenberg PS, Hollenbeck AR, Leitzmann M, Schatzkin A: Dietary fat and postmenopausal invasive breast cancer in the National Institutes of Health-AARP Diet and Health Study cohort. I Natl Cancer Inst 2007, 99:451-462.

18. Olson LK, Tan Y, Zhao Y, Aupperlee MD, Haslam SZ: Pubertal exposure to high fat diet causes mouse strain-dependent alterations in mammary gland development and estrogen responsiveness. Int J Obes (Lond) 2010, 34:1415-1426

19. Banerjee MR, Wood BG, Lin FK, Crump LR: Organ culture of whole mammary gland of the mouse. Tissue Culture Association Manual 1976, 2:457-462. 
20. Aupperlee MD, Smith KT, Kariagina A, Haslam SZ: Progesterone receptor isoforms $\mathrm{A}$ and $\mathrm{B}$ : temporal and spatial differences in expression during murine mammary gland development. Endocrinology 2005, 146:3577-3588.

21. Matsui Y, Halter SA, Holt JT, Hogan BL, Coffey RJ: Development of mammary hyperplasia and neoplasia in MMTV-TGF alpha transgenic mice. Cell 1990, 61:1147-1155.

22. Cardiff RD, Anver MR, Gusterson BA, Hennighausen L, Jensen RA, Merino MJ, Rehm S, Russo J, Tavassoli FA, Wakefield LM, Ward JM, Green JE: The mammary pathology of genetically engineered mice: the consensus report and recommendations from the Annapolis meeting. Oncogene 2000 19:968-988.

23. McGuinness OP, Ayala JE, Laughlin MR, Wasserman DH: NIH experiment in centralized mouse phenotyping: the Vanderbilt experience and recommendations for evaluating glucose homeostasis in the mouse. Am J Physiol Endocrinol Metab 2009, 297:E849-E855.

24. Allred DC, Harvey JM, Berardo M, Clark GM: Prognostic and predictive factors in breast cancer by immunohistochemical analysis. Mod Pathol 1998, 11:155-168.

25. Duffy JP, Smith PJ, Croker J, Matthews HR: Combined staining method for the demonstration of tissue eosinophils and mast cells. The Journal of Histotechnology 1993, 16:143-144.

26. $\mathrm{RT}^{2}$ Profiler PCR Array Data Analysis, version 3.5. http://pcrdataanalysis. sabiosciences.com/pcr/arrayanalysis.php.

27. Myers JL, Well AD: Research Design and Statistical Analysis. 2nd edition. Mahwah, NJ: Lawrence Erlbaum; 2003.

28. Aupperlee MD, Drolet AA, Durairaj S, Wang W, Schwartz RC, Haslam SZ: Strain-specific differences in the mechanisms of progesterone regulation of murine mammary gland development. Endocrinology 2009, 150:1485-1494.

29. Mulac-Jericevic B, Lydon JP, DeMayo FJ, Conneely OM: Defective mammary gland morphogenesis in mice lacking the progesterone receptor $B$ isoform. Proc Natl Acad Sci USA 2003, 100:9744-9749.

30. Srivastava S, Matsuda M, Hou Z, Bailey JP, Kitazawa R, Herbst MP, Horseman ND: Receptor activator of NF-kappaB ligand induction via Jak2 and Stat5a in mammary epithelial cells. J Biol Chem 2003, 278:46171-46178.

31. Bates SE, Valverius EM, Ennis BW, Bronzert DA, Sheridan JP, Stampfer MR, Mendelsohn J, Lippman ME, Dickson RB: Expression of the transforming growth factor-alpha/epidermal growth factor receptor pathway in normal human breast epithelial cells. Endocrinology 1990, 126:596-607.

32. Beyer TA, Narimatsu M, Weiss A, David L, Wrana JL: The TGFbeta superfamily in stem cell biology and early mammalian embryonic development. Biochimica et biophysica acta 2013, 1830:2268-2279.

33. Venkitaraman AR: Cancer susceptibility and the functions of BRCA1 and BRCA2. Cell 2002, 108:171-182.

34. Dallol A, Morton D, Maher ER, Latif F: SLIT2 axon guidance molecule is frequently inactivated in colorectal cancer and suppresses growth of colorectal carcinoma cells. Cancer Res 2003, 63:1054-1058.

35. Prosser J, Thompson AM, Cranston G, Evans HJ: Evidence that p53 behaves as a tumour suppressor gene in sporadic breast tumours. Oncogene 1990, 5:1573-1579.

36. Soengas MS, Alarcon RM, Yoshida H, Giaccia AJ, Hakem R, Mak TW, Lowe SW: Apaf-1 and caspase-9 in p53-dependent apoptosis and tumor inhibition. Science 1999, 284:156-159.

37. Nishikawa S, Doi K, Nakayama H, Uetsuka K: The effect of fasting on hepatic lipid accumulation and transcriptional regulation of lipid metabolism differs between C57BL/6 J and BALB/CA mice fed a high-fat diet. Toxicol Pathol 2008, 36:850-857.

38. Gonzalez-Suarez E, Branstetter D, Armstrong A, Dinh H, Blumberg H, Dougall WC: RANK Overexpression in Transgenic Mice with Mouse Mammary Tumor Virus Promoter-Controlled RANK Increases Proliferation and Impairs Alveolar Differentiation in the Mammary Epithelia and Disrupts Lumen Formation in Cultured Epithelial Acini. Mol Cell Biol 2007, 27:1442-1454.

39. Fernandez-Valdivia R, Mukherjee A, Ying Y, Li J, Paquet M, DeMayo FJ, Lydon JP: The RANKL signaling axis is sufficient to elicit ductal sidebranching and alveologenesis in the mammary gland of the virgin mouse. Dev Biol 2009, 328:127-139.

40. Beleut M, Rajaram RD, Caikovski M, Ayyanan A, Germano D, Choi Y, Schneider $\mathrm{P}$, Brisken C: Two distinct mechanisms underlie progesteroneinduced proliferation in the mammary gland. Proc Natl Acad Sci USA 2010, 107:2989-2994.
41. Yasuda H, Shima N, Nakagawa N, Yamaguchi K, Kinosaki M, Mochizuki S, Tomoyasu A, Yano K, Goto M, Murakami A, Tsuda E, Morinaga T, Higashio K, Udagawa N, Takahashi N, Suda T: Osteoclast differentiation factor is a ligand for osteoprotegerin/osteoclastogenesis-inhibitory factor and is identical to TRANCE/RANKL. Proc Natl Acad Sci USA 1998 95:3597-3602.

42. Kleinberg DL, Feldman M, Ruan W: IGF-I: an essential factor in terminal end bud formation and ductal morphogenesis. J Mammary Gland Biol Neoplasia 2000, 5:7-17.

43. Kleinberg DL, Wood TL, Furth PA, Lee AV: Growth hormone and insulinlike growth factor-I in the transition from normal mammary development to preneoplastic mammary lesions. Endocr Rev 2009, 30:51-74.

44. Yang J, Liao D, Chen C, Liu Y, Chuang TH, Xiang R, Markowitz D, Reisfeld RA, Luo $Y$ : Tumor associated macrophages regulate murine breast cancer stem cells through a novel paracrine EGFR/Stat3/Sox-2 signaling pathway. Stem cells (Dayton, Ohio) 2012, 31:248-258.

45. Li MO, Flavell RA: TGF-beta: a master of all T cell trades. Cell 2008, 134:392-404.

46. Massague J: TGFbeta in Cancer. Cell 2008, 134:215-230.

47. Wu MY, Hill CS: Tgf-beta superfamily signaling in embryonic development and homeostasis. Dev Cell 2009, 16:329-343.

48. Derynck R, Miyazono K: The TGF-Beta Family. Cold Spring Harbor, NY: Laboratory Press; 2008

49. Ewan KB, Shyamala G, Ravani SA, Tang Y, Akhurst R, Wakefield L, BarcellosHoff MH: Latent transforming growth factor-beta activation in mammary gland: regulation by ovarian hormones affects ductal and alveolar proliferation. Am J Pathol 2002, 160:2081-2093.

50. Ingman W, Robertson SA: Mammary gland development in transforming growth factor beta1 null mutant mice: systemic and epithelial effects. Biol Reprod 2008, 79:711-717.

51. Nelson CM, Vanduijn MM, Inman JL, Fletcher DA, Bissell MJ: Tissue geometry determines sites of mammary branching morphogenesis in organotypic cultures. Science 2006, 314:298-300.

52. Wechselberger C, Strizzi L, Kenney N, Hirota M, Sun Y, Ebert A, Orozco O, Bianco C, Khan NI, Wallace-Jones B, Normanno N, Adkins H, Sanicola M, Salomon DS: Human Cripto-1 overexpression in the mouse mammary gland results in the development of hyperplasia and adenocarcinoma. Oncogene 2005, 24:4094-4105.

53. Sakuma R, Ohnishi Yi Y, Meno C, Fujii H, Juan H, Takeuchi J, Ogura T, Li E, Miyazono K, Hamada $\mathrm{H}$ : Inhibition of Nodal signalling by Lefty mediated through interaction with common receptors and efficient diffusion. Genes Cells 2002, 7:401-412

54. Shay JW, Wright WE: Senescence and immortalization: role of telomeres and telomerase. Carcinogenesis 2005, 26:867-874.

55. Shay JW, Bacchetti S: A survey of telomerase activity in human cancer. Eur J Cancer 1997, 33:787-791.

56. Al-Rawi MA, Rmali K, Watkins G, Mansel RE, Jiang WG: Aberrant expression of interleukin-7 (IL-7) and its signalling complex in human breast cancer. Eur J Cancer 2004, 40:494-502.

57. Garcia-Tunon I, Ricote M, Ruiz A, Fraile B, Paniagua R, Royuela M: Interleukin-2 and its receptor complex (alpha, beta and gamma chains) in in situ and infiltrative human breast cancer: an immunohistochemical comparative study. Breast Cancer Res 2004, 6:R1-R7.

58. Wang D, Huang P, Zhu B, Sun L, Huang Q, Wang J: Induction of estrogen receptor alpha-36 expression by bone morphogenetic protein 2 in breast cancer cell lines. Molecular Medicine Reports 2012, 6:591-596.

59. Yan H, Zhu S, Song C, Liu N, Kang J: Bone morphogenetic protein (BMP) signaling regulates mitotic checkpoint protein levels in human breast cancer cells. Cell Signal 2012, 24:961-968.

60. Sakai H, Furihata M, Matsuda C, Takahashi M, Miyazaki H, Konakahara T, Imamura T, Okada T: Augmented autocrine bone morphogenic protein (BMP) 7 signaling increases the metastatic potential of mouse breast cancer cells. Clin Exp Metastasis 2012, 29:327-338.

61. Turner N, Grose R: Fibroblast growth factor signalling: from development to cancer. Nature Reviews 2010, 10:116-129.

62. Ye L, Bokobza S, Li J, Moazzam M, Chen J, Mansel RE, Jiang WG: Bone morphogenetic protein-10 (BMP-10) inhibits aggressiveness of breast cancer cells and correlates with poor prognosis in breast cancer. Cancer Sci 2010, 101:2137-2144.

63. Pandini G, Vigneri R, Costantino A, Frasca F, Ippolito A, Fujita-Yamaguchi $Y$, Siddle K, Goldfine ID, Belfiore A: Insulin and insulin-like growth factor-I 
(IGF-I) receptor overexpression in breast cancers leads to insulin/IGF-I hybrid receptor overexpression: evidence for a second mechanism of IGF-I signaling. Clin Cancer Res 1999, 5:1935-1944.

64. Papa V, Gliozzo B, Clark GM, McGuire WL, Moore D, Fujita-Yamaguchi Y, Vigneri R, Goldfine ID, Pezzino V: Insulin-like growth factor-I receptors are overexpressed and predict a low risk in human breast cancer. Cancer Res 1993, 53:3736-3740.

65. Peyrat JP, Bonneterre J: Type 1 IGF receptor in human breast diseases. Breast Cancer Res Treat 1992, 22:59-67.

66. Pezzino V, Papa V, Milazzo G, Gliozzo B, Russo P, Scalia PL: Insulin-like growth factor-I (IGF-I) receptors in breast cancer. Ann N Y Acad Sci 1996, 784:189-201.

67. Reis FM, Luisi S, Carneiro MM, Cobellis L, Federico M, Camargos AF, Petraglia F: Activin, inhibin and the human breast. Mol Cell Endocrinol 2004, 225:77-82

68. Evron E, Umbricht CB, Korz D, Raman V, Loeb DM, Niranjan B, Buluwela L, Weitzman SA, Marks J, Sukumar S: Loss of cyclin D2 expression in the majority of breast cancers is associated with promoter hypermethylation. Cancer Res 2001, 61:2782-2787.

69. Kong G, Chua SS, Yijun Y, Kittrell F, Moraes RC, Medina D, Said TK: Functional analysis of cyclin D2 and p27(Kip1) in cyclin D2 transgenic mouse mammary gland during development. Oncogene 2002, 21:7214-7225.

70. Ouchi T, Monteiro AN, August A, Aaronson SA, Hanafusa H: BRCA1 regulates p53-dependent gene expression. Proc Natl Acad Sci USA 1998, 95:2302-2306.

71. Hickman ES, Helin K: The regulation of APAF1 expression during development and tumourigenesis. Apoptosis 2002, 7:167-171.

72. Duesberg P, Li R, Rasnick D, Rausch C, Willer A, Kraemer A, Yerganian G, Hehlmann R: Aneuploidy precedes and segregates with chemical carcinogenesis. Cancer Genet Cytogenet 2000, 119:83-93.

73. Moll R, Franke WW, Volc-Platzer B, Krepler R: Different keratin polypeptides in epidermis and other epithelia of human skin: a specific cytokeratin of molecular weight 46,000 in epithelia of the pilosebaceous tract and basal cell epitheliomas. J Cell Biol 1982, 95:285-295.

74. Wilson CA, Dering J: Recent translational research: microarray expression profiling of breast cancer-beyond classification and prognostic markers? Breast Cancer Res 2004, 6:192-200.

75. Incassati A, Chandramouli A, Eelkema R, Cowin P: Key signaling nodes in mammary gland development and cancer: beta-catenin. Breast Cancer Res 2010, 12:213.

76. Haslam SZ, Woodward TL: Host microenvironment in breast cancer development: epithelial-cell-stromal-cell interactions and steroid hormone action in normal and cancerous mammary gland. Breast Cancer Res 2003, 5:208-215

77. Sierra JR, Tsao MS: c-MET as a potential therapeutic target and biomarker in cancer. Ther Adv Med Oncol 2011, 3:S21-S35.

78. Ahmed HH, Metwally FM, Mahdy ES, Shosha WG, Ramadan SS: Clinical value of serum hepatocyte growth factor, B-cell lymphoma-2 and nitric oxide in primary breast cancer patients. Eur Rev Med Pharmacol Sci 2012, 16:958-965.

79. Rosemary Siafakas A, Richardson DR: Growth arrest and DNA damage-45 alpha (GADD45alpha). Int J Biochem Cell Biol 2009, 41:986-989.

80. Reinhardt HC, Schumacher B: The p53 network: cellular and systemic DNA damage responses in aging and cancer. Trends Genet 2012, 28:128-136.

81. Blancafort P, Ouyuky Juarez K, Stolzenburg S, Beltran AS: Engineering transcription factors in breast cancer. In Breast Cancer-Carcinogenesis, Cell Growth and Signalling Pathways. Edited by Gunduz PM. Rijeka, Croatia: InTech; 2011.

82. Iwamoto T, Booser D, Valero V, Murray JL, Koenig K, Esteva FJ, Ueno NT, Zhang J, Shi W, Qi Y, Matsuoka J, Yang EJ, Hortobagyi GN, Hatzis C, Symmans WF, Pusztai L: Estrogen receptor (ER) mRNA and ER-related gene expression in breast cancers that are 1\% to 10\% ER-positive by immunohistochemistry. J Clin Oncol 2012, 30:729-734.

83. Millikan RC, Newman B, Tse CK, Moorman PG, Conway K, Dressler LG, Smith LV, Labbok MH, Geradts J, Bensen JT, Jackson S, Nyante S, Livasy C, Carey L, Earp HS, Perou CM: Epidemiology of basal-like breast cancer. Breast Cancer Res Treat 2008, 109:123-139.

84. Bar-Eli M: Back to the embryonic stage: Nodal as a biomarker for breast cancer progression. Breast Cancer Res 2012, 14:105.

85. Kirschmann DA, Seftor EA, Hardy KM, Seftor RE, Hendrix MJ: Molecular pathways: vasculogenic mimicry in tumor cells: diagnostic and therapeutic implications. Clin Cancer Res 2012, 18:2726-2732.

86. Yamashita H, Shimizu A, Kato M, Nishitoh H, Ichijo H, Hanyu A, Morita I, Kimura M, Makishima F, Miyazono K: Growth/differentiation factor-5 induces angiogenesis in vivo. Exp Cell Res 1997, 235:218-226.
87. Maae E, Olsen DA, Steffensen KD, Jakobsen EH, Brandslund I, Sorensen FB, Jakobsen A: Prognostic impact of placenta growth factor and vascular endothelial growth factor $A$ in patients with breast cancer. Breast Cancer Res Treat 2012, 133:257-265.

88. Orimo A, Gupta PB, Sgroi DC, Arenzana-Seisdedos F, Delaunay T, Naeem R, Carey VJ, Richardson AL, Weinberg RA: Stromal fibroblasts present in invasive human breast carcinomas promote tumor growth and angiogenesis through elevated SDF-1/CXCL12 secretion. Cell 2005, 121:335-348.

89. Boimel PJ, Smirnova T, Zhou ZN, Wyckoff J, Park H, Coniglio SJ, Qian BZ, Stanley ER, Cox D, Pollard JW, Muller WJ, Condeelis J, Segall JE: Contribution of CXCL12 secretion to invasion of breast cancer cells. Breast Cancer Res 2012, 14:R23.

90. Faupel-Badger JM, Ginsburg E, Fleming JM, Susser L, Doucet T, Vonderhaar BK: $16 \mathrm{kDa}$ prolactin reduces angiogenesis, but not growth of human breast cancer tumors in vivo. Hormones \& Cancer 2010, 1:71-79.

91. Verbeke S, Meignan S, Lagadec C, Germain E, Hondermarck H, Adriaenssens $E$, Le Bourhis X: Overexpression of p75(NTR) increases survival of breast cancer cells through p21(waf1). Cell Signal 2010, 22:1864-1873.

92. Yamada-Goto N, Katsuura G, Ochi Y, Ebihara K, Kusakabe T, Hosoda K, Nakao K: Impairment of fear-conditioning responses and changes of brain neurotrophic factors in diet-induced obese mice. J Neuroendocrinol 2012, 24:1120-1125.

93. Skaper SD: The neurotrophin family of neurotrophic factors: an overview. Methods Mol Biol 2012, 846:1-12.

94. Forssmann $U$, Uguccioni M, Loetscher $P$, Dahinden CA, Langen $H$, Thelen $M$, Baggiolini M: Eotaxin-2, a novel CC chemokine that is selective for the chemokine receptor CCR3, and acts like eotaxin on human eosinophil and basophil leukocytes. J Exp Med 1997, 185:2171-2176.

95. Post TW, Bozic CR, Rothenberg ME, Luster AD, Gerard N, Gerard C: Molecular characterization of two murine eosinophil beta chemokine receptors. J Immunol 1995, 155:5299-5305.

96. Yamaguchi $Y$, Hayashi $Y$, Sugama $Y$, Miura $Y$, Kasahara T, Kitamura S, Torisu M, Mita S, Tominaga A, Takatsu K: Highly purified murine interleukin 5 (IL5) stimulates eosinophil function and prolongs in vitro survival. IL-5 as an eosinophil chemotactic factor. J Exp Med 1988, 167:1737-1742.

97. Wu D, Molofsky AB, Liang HE, Ricardo-Gonzalez RR, Jouihan HA, Bando JK, Chawla A, Locksley RM: Eosinophils sustain adipose alternatively activated macrophages associated with glucose homeostasis. Science 2011, 332:243-247.

98. Darnay BG, Haridas V, Ni J, Moore PA, Aggarwal BB: Characterization of the intracellular domain of receptor activator of NF-kappaB (RANK), Interaction with tumor necrosis factor receptor-associated factors and activation of NFkappab and c-Jun N-terminal kinase. J Biol Chem 1998, 273:20551-20555.

99. van Asseldonk EJ, Stienstra R, Koenen TB, van Tits $\sqcup$, Joosten LA, Tack CJ, Netea MG: The effect of the interleukin-1 cytokine family members IL-1 F6 and IL1 F8 on adipocyte differentiation. Obesity (Silver Spring) 2010, 18:2234-2236.

100. Chen KJ, Lin SZ, Zhou L, Xie HY, Zhou WH, Taki-Eldin A, Zheng SS: Selective recruitment of regulatory T cell through CCR6-CCL20 in hepatocellular carcinoma fosters tumor progression and predicts poor prognosis. Plos one 2011, 6:e24671.

101. Hoelzinger DB, Smith SE, Mirza N, Dominguez AL, Manrique SZ, Lustgarten J: Blockade of CCL1 inhibits T regulatory cell suppressive function enhancing tumor immunity without affecting $T$ effector responses. J Immunol 2010, 184:6833-6842.

102. Mizukami Y, Kono K, Kawaguchi Y, Akaike H, Kamimura K, Sugai H, Fujii H: CCL17 and CCL22 chemokines within tumor microenvironment are related to accumulation of Foxp3+ regulatory T cells in gastric cancer. Int J Cancer 2008, 122:2286-2293.

103. Liu J, Zhang N, Li Q, Zhang W, Ke F, Leng Q, Wang H, Chen J: Tumorassociated macrophages recruit CCR6+ regulatory $T$ cells and promote the development of colorectal cancer via enhancing CCL20 production in mice. Plos one 2011, 6:e19495.

104. Gordon S: Alternative activation of macrophages. Nat Rev Immunol 2003, 3:23-35

105. Sun X, Robertson SA, Ingman WV: Regulation of epithelial cell turnover and macrophage phenotype by epithelial cell-derived transforming growth factor beta1 in the mammary gland. Cytokine 2013, 61:377-388.

106. Beider K, Abraham M, Begin M, Wald H, Weiss ID, Wald O, Pikarsky E, Abramovitch R, Zeira E, Galun E, Nagler A, Peled A: Interaction between CXCR4 and CCL20 pathways regulates tumor growth. PloS one 2009, 4:e5125.

107. Cassier PA, Treilleux I, Bachelot T, Ray-Coquard I, Bendriss-Vermare N, Menetrier-Caux C, Tredan O, Goddard-Leon S, Pin JJ, Mignotte H, 
Bathélémy-Dubois C, Caux C, Lebecque S, Blay JY: Prognostic value of the expression of C-Chemokine Receptor 6 and 7 and their ligands in nonmetastatic breast cancer. BMC cancer 2011, 11:213.

108. Nannuru KC, Sharma B, Varney ML, Singh RK: Role of chemokine receptor CXCR2 expression in mammary tumor growth, angiogenesis and metastasis. J Carcinog 2011, 10:40.

109. Blank M, Krause I, Buskila D, Teitelbaum D, Kopolovic J, Afek A, Goldberg I, Shoenfeld $Y$ : Bromocriptine immunomodulation of experimental SLE and primary antiphospholipid syndrome via induction of nonspecific T suppressor cells. Cell Immunol 1995, 162:114-122.

110. Naseemuddin M, Iqbal A, Nasti TH, Ghandhi JL, Kapadia AD, Yusuf N: Cell mediated immune responses through TLR4 prevents DMBA-induced mammary carcinogenesis in mice. Int J Cancer 2012, 130:765-774.

111. Kinne RW, Brauer R, Stuhlmuller B, Palombo-Kinne E, Burmester GR: Macrophages in rheumatoid arthritis. Arthritis Res 2000, 2:189-202.

112. Paleolog EM: Angiogenesis in rheumatoid arthritis. Arthritis Res 2002, 4:S81-S90.

113. Wynn TA, Barron L: Macrophages: master regulators of inflammation and fibrosis. Semin Liver Dis 2010, 30:245-257.

114. Qian BZ, Pollard JW: Macrophage diversity enhances tumor progression and metastasis. Cell 2010, 141:39-51.

115. Aggarwal BB, Gehlot P: Inflammation and cancer: how friendly is the relationship for cancer patients? Curr Opin Pharmacol 2009, 9:351-369.

116. Magne J, Mariotti F, Fischer R, Mathe V, Tome D, Huneau JF: Early postprandial low-grade inflammation after high-fat meal in healthy rats: possible involvement of visceral adipose tissue. J Nutr Biochem 2010, 21:550-555.

117. Erridge $C$, Attina T, Spickett CM, Webb DJ: A high-fat meal induces lowgrade endotoxemia: evidence of a novel mechanism of postprandial inflammation. Am J Clin Nutr 2007, 86:1286-1292.

118. Suganami T, Mieda T, Itoh M, Shimoda Y, Kamei Y, Ogawa Y: Attenuation of obesity-induced adipose tissue inflammation in $\mathrm{C} 3 \mathrm{H} / \mathrm{HeJ}$ mice carrying a Toll-like receptor 4 mutation. Biochem Biophys Res Commun 2007, 354:45-49.

119. Renaud SC, Ruf JC, Petithory D: The positional distribution of fatty acids in palm oil and lard influences their biologic effects in rats. J Nutr 1995, 125:229-237.

120. Boni-Schnetzler M, Boller S, Debray S, Bouzakri K, Meier DT, Prazak R, KerrConte J, Pattou F, Ehses JA, Schuit FC, Donath MY: Free fatty acids induce a proinflammatory response in islets via the abundantly expressed interleukin-1 receptor I. Endocrinology 2009, 150:5218-5229.

121. Dasu MR, Jialal I: Free fatty acids in the presence of high glucose amplify monocyte inflammation via toll-like receptors. Am J Physiol Endocrinol Metab 2011, 300:E145-E154.

122. Rivera CA, Gaskin L, Singer G, Houghton J, Allman M: Western diet enhances hepatic inflammation in mice exposed to cecal ligation and puncture. BMC Physiol 2010, 10:20.

123. Wang Z, Liu D, Wang F, Liu S, Zhao S, Ling EA, Hao A: Saturated fatty acids activate microglia via Toll-like receptor 4/NF-kappaB signalling. Br J Nutr 2012, 107:229-241.

124. Grunfeld C, Feingold KR: Regulation of lipid metabolism by cytokines during host defense. Nutrition 1996, 12:S24-S26.

125. Jansson JO, Moverare-Skrtic S, Berndtsson A, Wernstedt I, Carlsten H, Ohlsson C: Leukemia inhibitory factor reduces body fat mass in ovariectomized mice. Eur J Endocrinol 2006, 154:349-354.

126. Metcalf D, Nicola NA, Gearing DP: Effects of injected leukemia inhibitory factor on hematopoietic and other tissues in mice. Blood 1990, 76:50-56.

127. Um JY, Rim HK, Kim SJ, Kim HL, Hong SH: Functional polymorphism of IL-1 alpha and its potential role in obesity in humans and mice. PloS one 2011, 6:e29524.

128. Huang $X$, Yang C, Luo Y, Jin C, Wang F, McKeehan WL: FGFR4 prevents hyperlipidemia and insulin resistance but underlies high-fat diet induced fatty liver. Diabetes 2007, 56:2501-2510.

129. Flint DJ, Travers MT, Barber MC, Binart N, Kelly PA: Diet-induced obesity impairs mammary development and lactogenesis in murine mammary gland. Am J Physiol Endocrinol Metab 2005, 288:E1179-E1187.

130. Hilakivi-Clarke L, Stoica A, Raygada M, Martin MB: Consumption of a highfat diet alters estrogen receptor content, protein kinase $C$ activity, and mammary gland morphology in virgin and pregnant mice and female offspring. Cancer Res 1998, 58:654-660.

131. Moral R, Escrich R, Solanas M, Vela E, Costa I, de Villa MC, Escrich E: Diets high in corn oil or extra-virgin olive oil provided from weaning advance sexual maturation and differentially modify susceptibility to mammary carcinogenesis in female rats. Nutr Cancer 2011, 63:410-420.

132. Cleary MP, Grande JP, Juneja SC, Maihle NJ: Diet-induced obesity and mammary tumor development in MMTV-neu female mice. Nutr Cancer 2004, 50:174-180.

133. Kim EJ, Choi MR, Park H, Kim M, Hong JE, Lee JY, Chun HS, Lee KW, Yoon Park JH: Dietary fat increases solid tumor growth and metastasis of $4 \mathrm{T1}$ murine mammary carcinoma cells and mortality in obesity-resistant BALB/c mice. Breast Cancer Res 2011, 13:R78.

doi:10.1186/bcr3561

Cite this article as: Zhao et al.: Pubertal high fat diet: effects on

mammary cancer development. Breast Cancer Research 2013 15:R100.

\section{Submit your next manuscript to BioMed Central and take full advantage of:}

- Convenient online submission

- Thorough peer review

- No space constraints or color figure charges

- Immediate publication on acceptance

- Inclusion in PubMed, CAS, Scopus and Google Scholar

- Research which is freely available for redistribution

Submit your manuscript at www.biomedcentral.com/submit
C Biomed Central 